Latvia University of Life Sciences and Technologies Latvijas Lauksaimniecības universitāte

\author{
Faculty of Food Technology \\ Pārtikas tehnologijas fakultāte
}

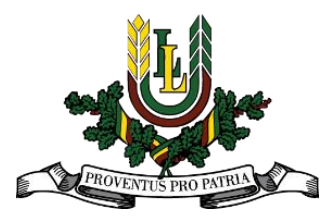

Mg.sc.ing. Igors Šepeḷevs

\title{
POTATO PROCESSING BY-PRODUCT EVALUATION FOR MICROENCAPSULATED PHENOLIC COMPOUND PRODUCTION
}

KARTUPELLU PĀRSTRĀDES BLAKUSPRODUKTU IZPĒTE MIKROKAPSULETU FENOLU SAVIENOJUMU IEGUVEI

\author{
SUMMARY of the Doctoral Dissertation \\ for the scientific degree of Dr. sc. ing. \\ Promocijas darba KOPSAVILKUMS \\ Dr. sc. ing. zinātniskā grāda iegūšanai
}

Jelgava

2018 
Scientific supervisor /

Promocijas darba vadītāja:

Prof., Dr.sc.ing. Ruta Galoburda

Official reviewers / Oficiälie recenzenti:

Leading researcher, Dr.sc.ing. Dalija Segliṇa (Institute of Horticulture / Dārzkopības institūts)

Leading researcher, Dr.agr. Ilze Skrabule (Institute of Agricultural Resources and Economics / Agroresursu un ekonomikas institūts)

Associated professor, Dr.sc.ing. Māra Dūma (Latvia University of Life Sciences and Technologies, Department of Chemistry / Latvijas Lauksaimniecības universitāte, Kìmijas katedra)

The research had been partially funded from the National Research Program (2014-2017) "Agricultural resources for sustainable production of qualitative and healthy food in Latvia (AgroBioRes)". Internship opportunity in the University of Minnesota had been granted by Baltic-American Freedom Foundation and Council on International Education Exchange.

Darba izstrāde lìdzfinansēta no Valsts pētījumu programmas "Lauksaimniecības resursi ilgtspējīgai kvalitatīvas un veselīgas pārtikas ražošanai Latvijā (AgroBioRes)” (2014.-2017.). Stažěšanās iespēja Minesotas Universitātē tika nodrošināta ar Baltijas-Amerikas Brī̄ības Fonda un Starptautiskās izglītības apmainas padomes atbalstu.

The defense of the dissertation in an open session of the Promotion Board of Food Science of Latvia University of Life Sciences and Technologies will be held on December 14, 2018, at 11 a.m. in auditorium 216 at the Faculty of Food Technology, 22 Rigas Street, Jelgava.

Promocijas darba aizstāvēšana notiks LLU Pārtikas zinātnes nozares promocijas padomes atklātajā sēde 2018. gada 14. decembrī plkst. $11^{00}$ Pārtikas tehnologijas fakultātē, 216. auditorijā, Rīgas ielā 22, Jelgavā.

The dissertation is available at the Fundamental library of the Latvia University of Life Sciences and Technologies, 2 Liela Street, Jelgava LV3001, and on the internet http://llufb.llu.lv/promoc_darbi_en.html. References should be sent to Dr.sc.ing. I. Beitāne, the Secretary of the Promotion Board of Food Science at the Faculty of Food Technology, Latvia University of Life Sciences and Technologies, 22 Rigas Street, Jelgava LV3004, Latvia or e-mail: ilze.beitane@llu.lv.

Ar promocijas darbu un kopsavilkumu var iepazīties LLU Fundamentālajā bibliotēkā, Lielā ielā 2, Jelgavā LV-3001, un internetā (pieejams: http://llufb.llu.lv/promoc_darbi_en.html). Atsauksmes sūtīt Pārtikas zinātnes nozares promocijas pādomes sekretārei, LLU Pārtikas tehnologijas fakultātes asoc. prof. Dr.sc.ing. I. Beitānei (Rìgas iela 22, Jelgava LV-3004, e-pasts:ilze.beitane@llu.lv). 


\section{CONTENT}

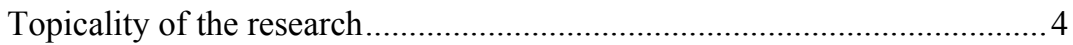

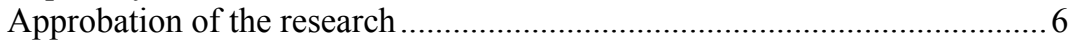

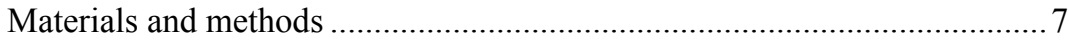

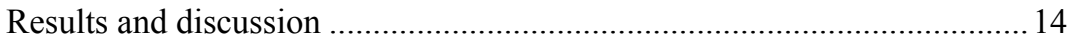

1. Evaluation of industrial potato processing by-products (peels) .............. 14

2. Extractable biologically active compound stability

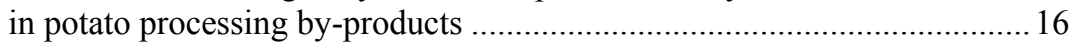

3. Comparison of spray-and freeze drying technologies

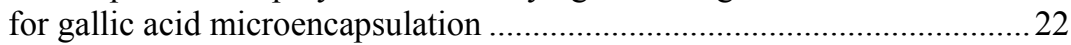

4. Water soluble phenolic compound encapsulation

in the multiple layer capsule .................................................................. 24

5. Simultaneous phenolic compound and carbohydrate extraction and further encapsulation ...................................................................... 27

6. Encapsulated recovered biologically active compound application

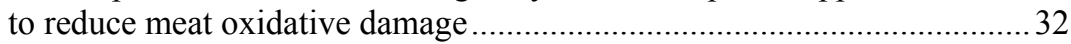

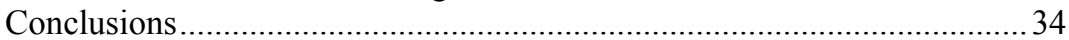

\section{SATURS}

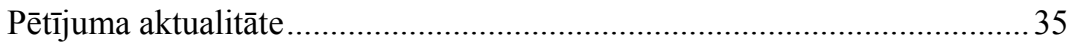

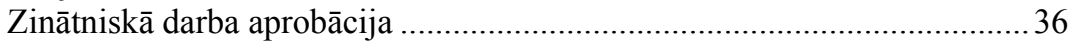

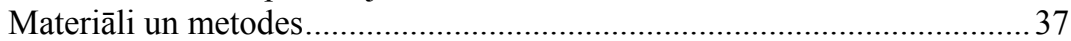

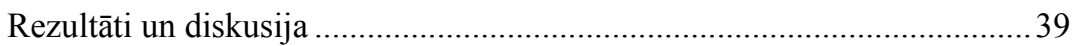

1. Kartupeḷu industriālas pārstrādes blakusproduktu (mizu) izvērtējums ...39

2. Ekstrahējamo bioloǵiski aktīvo vielu stabilitāte

kartupeḷu pārstrādes blakusproduktos ..........................................................39

3. Liofilizācijas un izsmidzināšanas kaltes metožu salīdzinājums

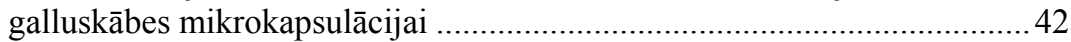

4. Ūdenī šḳistošo fenolu savienojumu mikrokapsulācija

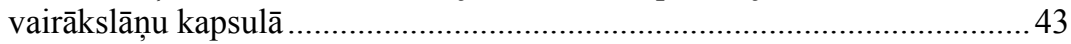

5. Vienlaicīga fenolu savienojumu uz og̣̣hidrātu ekstrakcija ar sekojošu mikrokapsulāciju

6. Mikrokapsulēto bioloǵiski aktīvo savienojumu pielietojums gaḷas

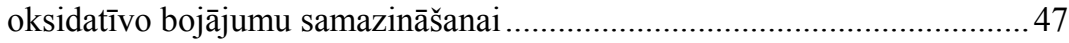

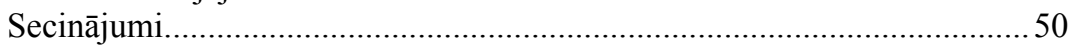




\section{TOPICALITY OF THE RESEARCH}

For years, potatoes (Solanum tuberosum L.) are one of the worlds' most important agricultural crops for human consumption after wheat (Triticum L.), rice (Oryza L.) and maize (Zea mays subsp. mays L.), with 374 million tonnes produced in 2016 worldwide, including 497 thousand tonnes in Latvia (FASOTAT, Crops, s.a.). At the same time, it had been reported that in some developed countries up to 70\% (in 2012) of total produced potatoes can be processed yearly (U.S. per Capita..., s.a.). Latvian economy is experiencing the steady growth and the increase in potato processing volumes could be expected also in the future.

Usually, industrial potato processing involves a peeling stage applying abrasion or steam methods that can generate up to $40 \%$ wastes of the initial potato mass, depending on the peeling method, final product, and quality of initial potato tubers (Arapoglou et al., 2009). Altogether, problem of industrial potato peel by-product (IPPB) management and utilisation makes a great concern for the potato industry. In Europe, processed potatoes (mainly frozen chips and crisps) were considered worth EUR 9.4 billion in 2015, or $1.1 \%$ of the overall value of European food and beverage industry (The EU potato sector, 2018).

Potato peel is one of the main potato processing wastes that have a big perspectives to be utilized as a raw material (Arapoglou et al., 2009). By chemical composition, IPPB is an inexpensive by-product that contains large quantities of starch and non-starch polysaccharides, and lignin. Although, too big fibre content makes it not suitable for non-ruminant diets without specialized treatment (Birch et al., 1981). Many theoretical studies had been conducted in the last decades on IPPB recycling, but no operational recycling facility is known at the moment of the present research. This fact indicates the necessity of developing a new scalable, cost-efficient, and compact method. Many authors agree that one of the perspective recycling possibilities of potato peel for application in food industry could be the biologically active compound (BAC) extraction. One of the main applications of the produced extract could be an enrichment of chosen food product in order to minimize its oxidation. Although, in order to ensure desired antioxidation properties, it is necessary to provide sufficient protection for the mentioned compounds before they will be delivered to the targeted production stage. One of the best solutions for this problem could be encapsulation of BAC, or BAC incorporation into a protective capsule. This will ensure the controlled release of encapsulated compound and minimize oxygen contact with potential antioxidants.

In order to develop a practically applicable method for potato peel (an industrial potato processing by-product) recycling, present thesis will focus on 
the development of BAC extraction and encapsulation, with further application of the produced encapsulated extract as an antioxidant for ground pork meat.

Hypotheses of the present work: potato peel - an industrial potato processing by-product, can be utilized for phenolic compound recovery and encapsulation, with further application in the food industry.

Research object - potato (Solanum tuberosum L.) peels, industrial potato processing by-product, collected from potato processing facilities in Latvia.

The aim of the present thesis was to develop a practically applicable recycling method for potato processing by-product, in order to produce a microencapsulated extract, containing biologically active (mostly phenolic) compounds.

To achieve the aim, following tasks had been established:

1. evaluate actual industrially available potato peels, a by-product from potato processing facilities in Latvia;

2. analyse the content and stability of extractable biologically active compounds in potato peels, that had been acquired by an abrasion peeling method;

3. compare the most common food grade methods for the extracted biologically active compound microencapsulation;

4. develop a method for production of microencapsulated phenolic compounds from industrial potato peel by-products, evaluating the functionality of produced capsules through the manufacture of a test food product.

\section{Scientific significance}

1. A unique complex method had been developed for the potato peel byproduct recycling and microencapsulated phenolic compound production.

2. Simultaneous extraction of biologically active compounds (mostly phenolic compounds) and carbohydrates (capsule wall material) with further encapsulation had been studied.

3. Produced product, fine powder, had been evaluated as a potential antioxidant for meat industry.

\section{Economic significance}

1. A practically applicable, compact (could be carried out within a one working day), and environmentally friendly potato peel recycling method had been developed, that allow to manufacture new products.

2. Produced encapsulated material is suitable for food product manufacturing in order to decrease oxidation rates and extend the shelf life. 


\section{APPROBATION OF THE RESEARCH}

Research results have been summarized and published in 5 scientific issues, including 3 publications indexed in the international citation databases SCOPUS and Web of Science.

\section{Publications indexed in international citation databases SCOPUS or Web of Science.}

1. Sepelevs I., Stepanova V., Galoburda R. (2018) Encapsulation of gallic acid with acid-modified low dextrose equivalent potato starch using spray- and freeze-drying techniques. Polish Journal of Food and Nutrition Science, 68(3), 273-280. https://doi.org/10.1515/pjfns-2018-0006

2. Shepelev I., Galoburda R., Rakcejeva T. (2016) Changes in the total phenol content in the industrial potato peel wastes during the storage. Agronomy Research, 14(S2), 1442-1450. ISSN: 1406-894X

3. Sepelev I., Galoburda R. (2015) Industrial potato peel waste application in food production: a review. Research for Rural Development, 1, 130136. ISSN: 1691-4031

\section{Publications in peer reviewed scientific isssues}

1. Sepelevs I., Reineccius G. (2018) Encapsulation of gallic acid in solid lipid core surrounded with maltodextrin shell. Agronomy Research, 16(S2), 1475-1485. https://doi.org/10.15159/AR.18.052

2. Шепелев И. Ю., Галобурда Р. Я., Ракчеева Т. В. (2015) Исследование отходов картофельного производства в Латвии. Низкотемпературные и пищевые технологии в ХХІ веке, с. 143-137. https://elibrary.ru/item.asp?id=25427601

Results have been presented at seven international scientific conferences and congresses in Brazil, Estonia, India, Latvia, Lithuania, and Russian Federation.

1. Sepelevs, I., Kince, T., Galoburda, R. "A method for encapsulated phenolic compound production from industrial potato peel wastes", 19th World Congress of Food Science and Technology "IUFoST 2018", Mumbai, India, 2018, October 23-27 (Poster presentation)

2. Sepelevs, I., Nakurte, I., Galoburda, R. "Degradation of bioactive compounds in potato processing wastes during the storage period at ambient conditions", 12th Baltic Conference of Food Science and Technology "FoodBalt 2018. Food R\&D in the Baltics and Beyond", Kaunas, Lithuania, 2018, May 17-18 (Poster presentation)

3. Sepelevs, I., Reineccius, G. "Encapsulation of Gallic acid in solid lipid core surrounded with maltodextrin shell", International Scientific 
Conference "Biosystems Engineering 2018", Tartu, Estonia, 2018, May 9-11 (Poster presentation)

4. Sepelevs, I., Reineccius, G. "Potato by-products as a material for biologically active compound extraction and encapsulation". International Training School "Reverse Engineering of Processed Foods", Campinas, Brazil, 2017, September 25th October to 4th (Poster presentation)

5. Shepelev, I., Galoburda, R., Rakcejeva, T. "Changes in the total phenol content in the industrial potato peel wastes during the storage", International Scientific Conference "Biosystems Engineering", Tartu, Estonia, 2016, May 25-26 (Poster presentation)

6. Sepelev, I., Galoburda, R. "Industrial potato peel waste application in food production: a review". Annual 21st International Scientific Conference "Research for Rural Development 2015", Jelgava, Latvia, 2015, May 13-15 (Oral presentation)

7. Шепелев, И. Ю., Галобурда, Р. Я., Ракчеева Т. В. “Исследование отходов картофельного производства в Латвии". VII Международная научно-техничесская конференция "Низкотемпературные и пищевые технологии в XXI веке", St. Petersburg, Russian Federation, 2015, October 17-20 (Oral presentation)

\section{MATERIALS AND METHODS}

\section{Time and place of the research}

Present thesis had been work out in the period from 2014 to 2018 in the scientific laboratories of the Latvia University of Life Sciences and Technologies (former Latvia University of Agriculture), and Department of Food Science and Nutrition, University of Minnesota (USA).

\section{Structure of the research}

Present research had been conducted in the three consequent stages that are represented in the Fig. 1.

In the first stage of the research, the main focus had been directed to the information gathering on possible potato by-product recycling in general and evaluation of the actual situation at potato processing facilities in Latvia. Low collaboration rates from the manufacturer side allowed to collect data and potato peel samples only form the following enterprises:

1. Ives Grupa, Ltd., Laveste, Jaunpils county;

2. Orkla Confectionery \& Snacks Latvija, Co. (former Latfood, Co.), currently the biggest potato processing company in Latvia;

3. Nissi, Ltd., Riga;

4. Paplate Nr.1, Ltd., Raubeni, Ozolnieki county. 


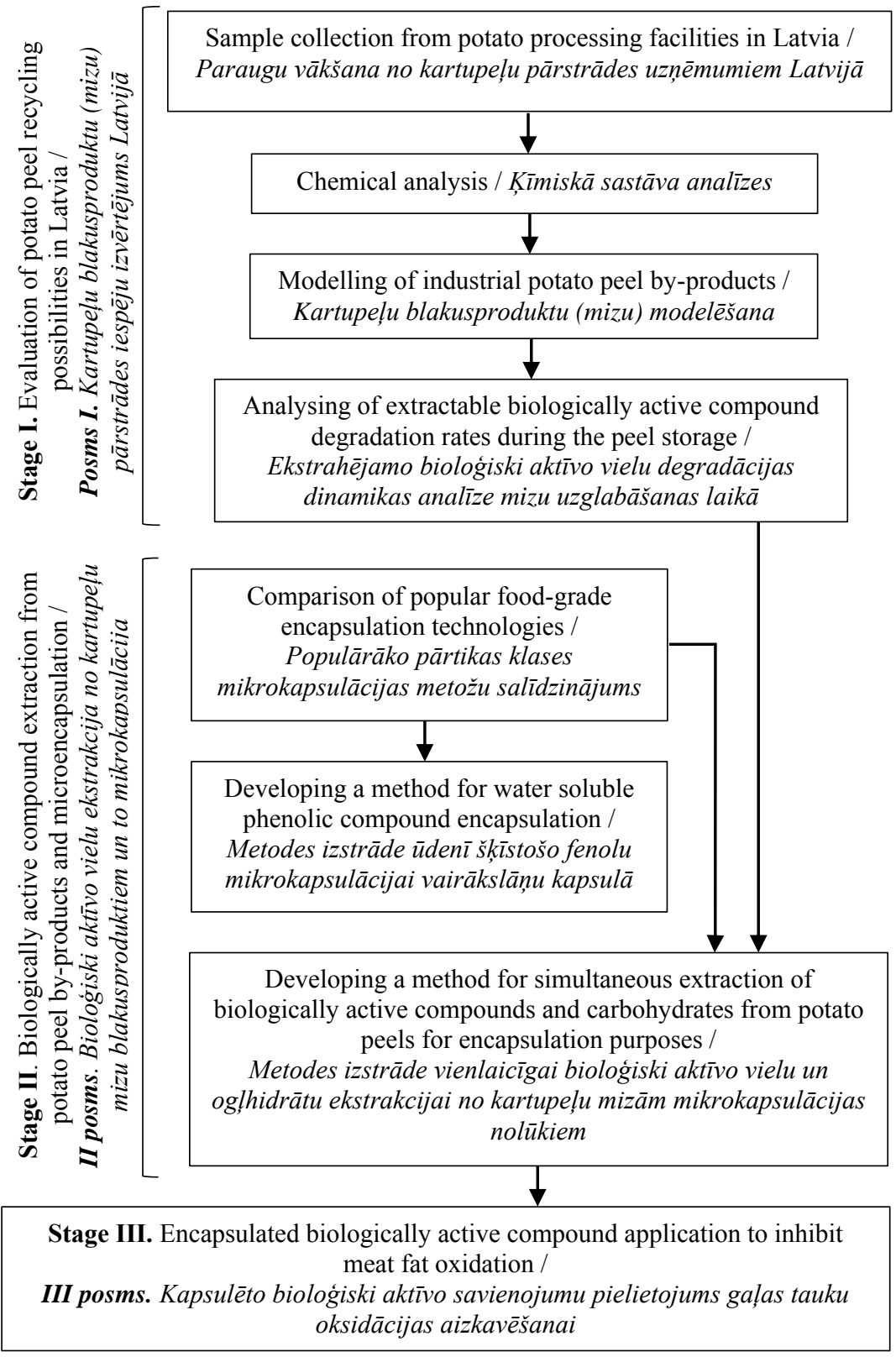

Fig. 1. Research structure /

1. att. Pêtīiuma struktūra 
After the chemical analysis of the collected potato peel samples, and acquired data evaluation, extractable BAC degradation rates in the peel samples stored at ambient conditions at room temperature had been evaluated, as it would be at the actual potato processing facility (Fig. 2).

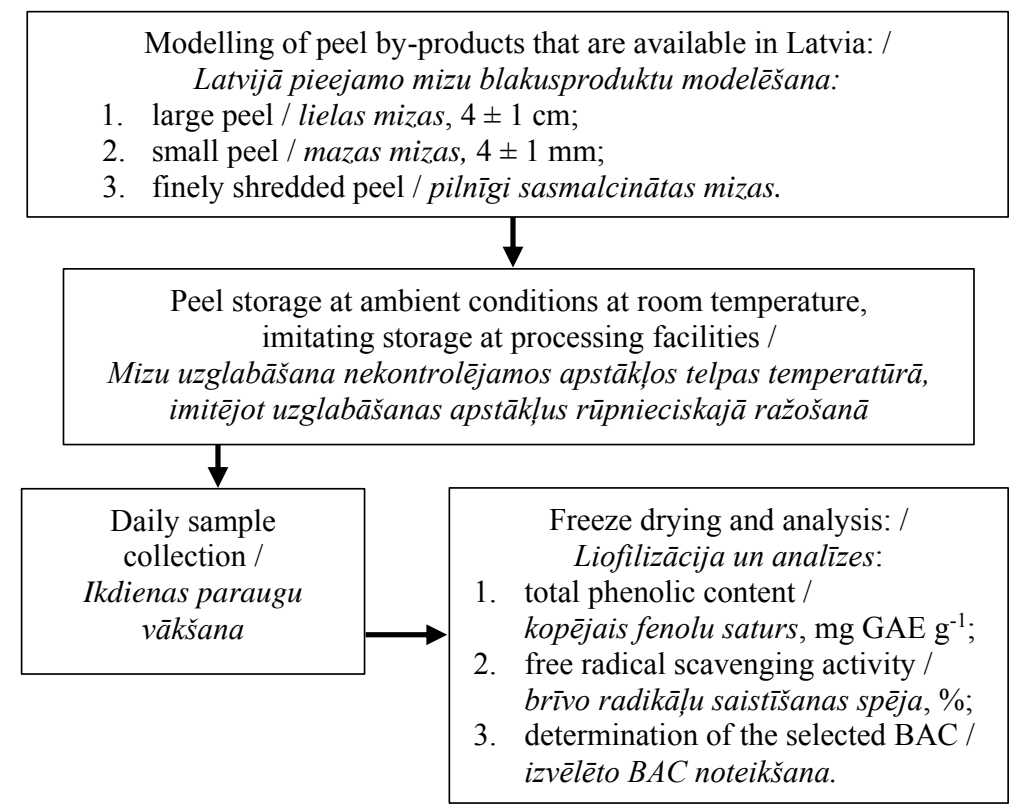

\section{Fig. 2. Evaluation of biologically active compounds (BAC) degradation rates /}

\section{2. att. Biologiski aktīvo vielu (BAC) degradācijas dinamikas novērtēšana}

To standardize different types of potato peel samples for this part of the research, an industrial grade potato variety had been chosen as a raw material and peel samples were prepared to match the ones acquired previously from the industry. For this step, potato samples (Solanum tuberosum cv Magdalena, pedigree 82-28.9/15876.41) were kindly donated by the Institute of Agricultural Resources and Economics (former State Priekuli Plant Breeding Institute). Prepared peel samples were stored for seven days in the open containers, at ambient conditions, shielded from the light.

After understanding the possible potato peel by-product storage and conditions, next step had been developed to evaluate existing popular foodgrade encapsulation methods (freeze- and spray-drying; Fig. 3). Originally, these methods are not comparable, and the main goal of the present step was to investigate whether the application of freeze-drying can be justified for non-thermo sensitive compound microencapsulation. Need of this study 
came from the fact that in many recent studies freeze-drying was proposed as the chosen method for BAC microencapsulation.

Gallic acid (GA) had been used as a model phenolic compound to ensure control conditions of the study, as it is common in nature, food grade, affordable, and relatively stable.

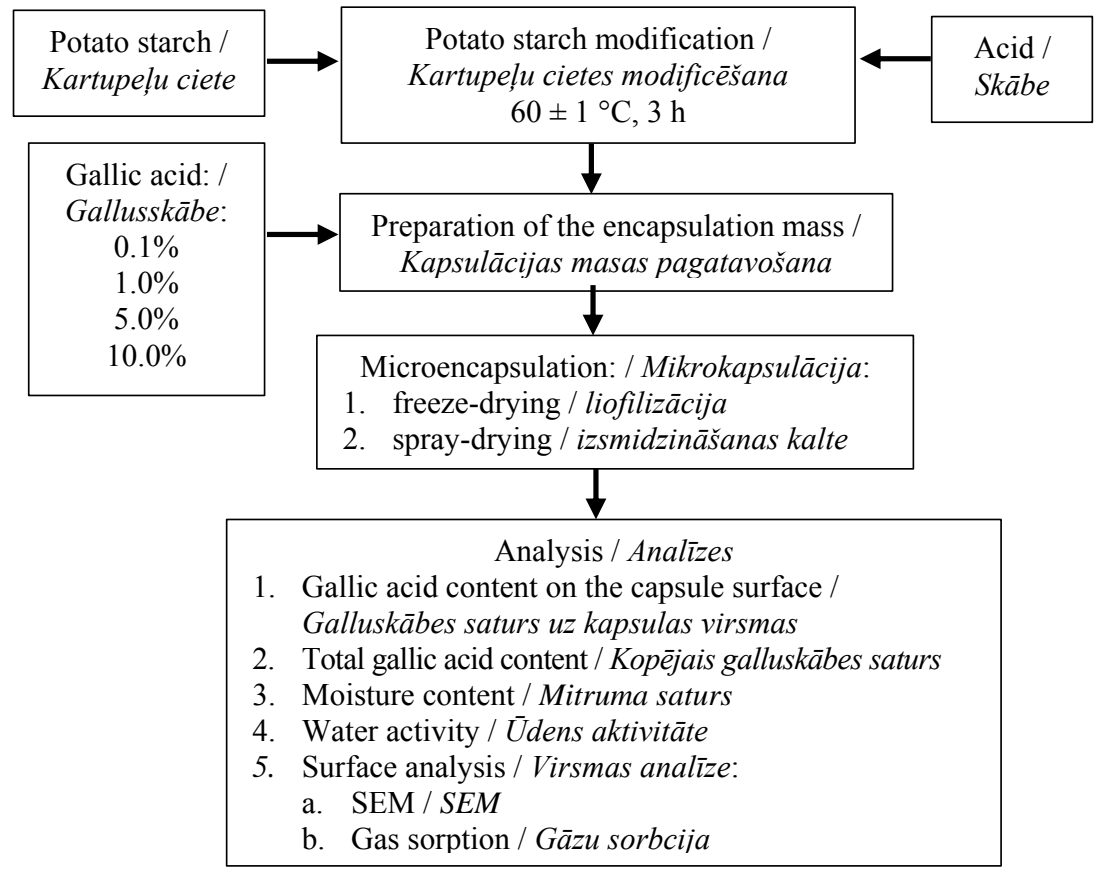

Fig. 3. Gallic acid microencapsulation by freeze- and spraydrying methods /

\section{3. att. Galluskābes mikrokapsulācija ar liofilizāciju un} izsmidzināšanu kaltēe

SEM - scanning electron microscope / skenējošais elektronu mikroskops

Based on the acquired results, spray-drying had been chosen as the microencapsulation technology. The next step had been designed to develop an alternative method for water soluble phenolic compound microencapsulation in the multiple layer capsule, in a single spray-drying process that can be seen in Fig. 4. Usually, similar methods imply multiple stages: 1) core material microencapsulation in the core of the capsule, 2) followed by the formation of the additional outer shell layer. Alternatively, the method developed in the present study allows to minimize time and costs of the production process, as it is the only step. In addition, to make an outer shell layer more resistant, small amounts of modified starch (chosen wall 
material) had been converted into the resistant starch. In the same way as it had been mentioned in the previous step, gallic acid had been used as the model phenolic compound.

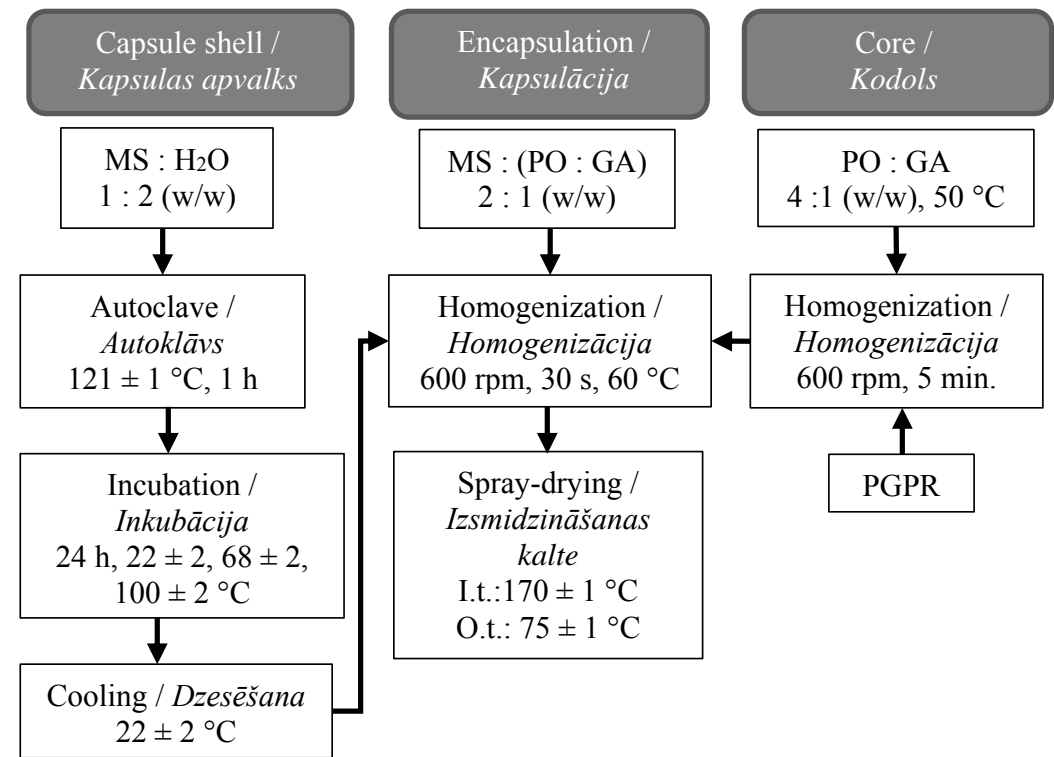

Fig. 4. Multiple phase capsule formation scheme /

4. att. Vairāku făžu kapsulu veidošanas shēma

$\mathrm{MS}$ - modified starch / modificēta ciete; $\mathrm{H}_{2} \mathrm{O}$ - water / üdens; $\mathrm{PO}$ - palm oil / palmu ella; GA - gallic acid (dry) / galluskābe (sausa); PGPR - polyglycerol polyricinoleate / poliglicerīna poliricinoleāts; I.t. - inlet temperature / ieejoša temperatūra; O.t. - outlet temperature / izejošă temperatūra.

After the deep analysis of acquired results from previous steps of both stages, the next step had been developed with an aim to provide an efficient and fast process for BAC extraction from the raw potato peel, and extracted compound microencapsulation, as it is shown in Fig. 5. To achieve this, simultaneous extraction of BAC and starch hydrolysis products had been introduced, with further spray-drying for microencapsulation purposes. It was planned that extracted carbohydrate will make a protective shell around BAC and incorporating of additional microencapsulation material will not be necessary. This allows to minimize production costs and time. 


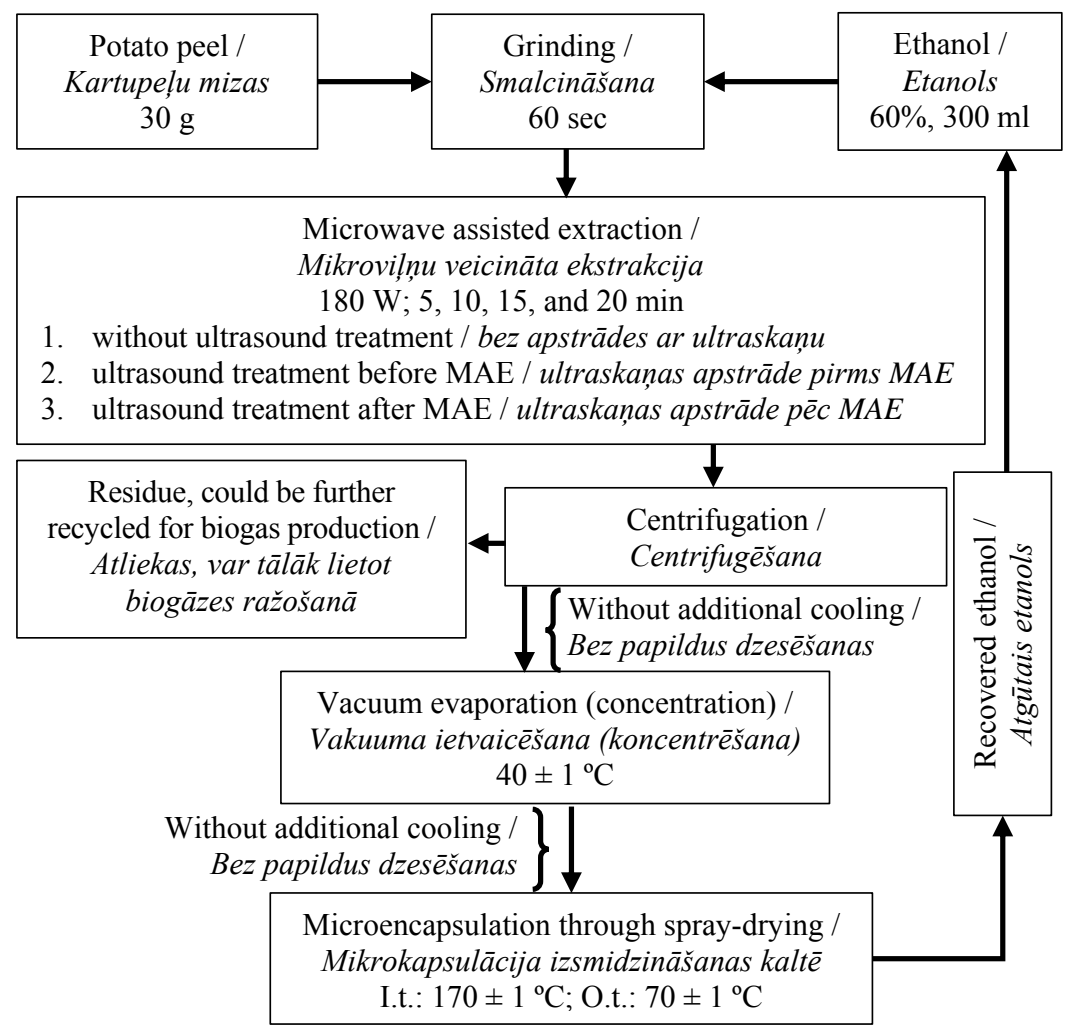

Fig. 5. Simultaneous biologically active compound and carbohydrate extraction with further microencapsulation

5. att. Biologiski aktīvo vielu un ogḷhidrātu vienlaicīga ekstrakcija ar sekojošu mikrokapsulāciju

MAE - microwave assisted extraction / mikroviln nu veicināta ekstrakcija;

I.t. - inlet temperature / ieplüdes temperatūra;

O.t. - outlet temperature /izplūdes temperatūra.

The last step of present work includes a practical application example of produced capsules. For the proof of concept study, freshly ground meat had been purchased and homogenized with produced capsules, containing BAC (Fig. 6). To achieve this, previously produced capsules were added to the ground pork meat mass in proportion $2 \mathrm{~g}$ of total measured phenols in capsules per $1 \mathrm{~kg}$ of total measured lipids in pork meat. Mass was homogenized in the kitchen type blender RHB450-S-W (Rotex, China) and stored at accelerated oxidation conditions at $30 \pm 1{ }^{\circ} \mathrm{C}$ for 6 days. Small amounts of samples had been taken daily, packed in vacuum, rapidly frozen and stored at $-20^{\circ} \mathrm{C}$ for further analysis. 


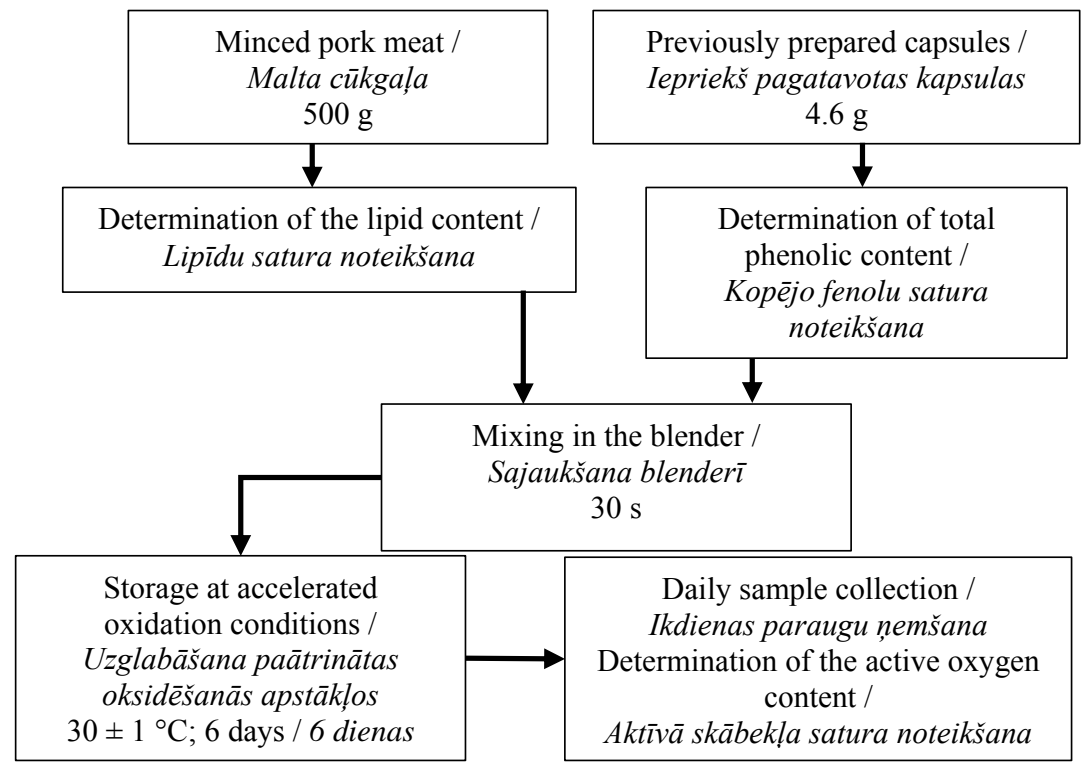

Fig. 6 . Minced pork meat processing with microencapsulated biologically active compounds /

6. att. Maltas cūkgaḷas apstrāde ar mikrokapsulētām biologiski aktīvām vielām

Methods applied for the research

Methods of analyses applied in the research are summarized in Table 1.

Applied methods / Pielietotās metodes

\begin{tabular}{|c|c|}
\hline $\begin{array}{l}\text { Parameters / } \\
\text { Raditâjji }\end{array}$ & $\begin{array}{l}\text { Standards and methods / } \\
\text { Standarti un metodes }\end{array}$ \\
\hline \multicolumn{2}{|c|}{ Physical parameters / Fizikālie rādìtāji } \\
\hline Moisture / Mitrums, \% & ISO 2171: 2010 \\
\hline Water activity / Ūdens aktivitāte, $\mathrm{a}_{\mathrm{w}}$ & ISO 21807: 2004 \\
\hline $\begin{array}{l}\text { Particle size and distribution / } \\
\text { Dalinu lielums un izméra sadalījums, } \mu \mathrm{m}\end{array}$ & LA 960 (HORIBA, Japan) \\
\hline $\begin{array}{l}\text { Amylose and amylopectin characterisation / } \\
\text { Amilozes un amilopektīna raksturojums }\end{array}$ & al., 2014 \\
\hline $\begin{array}{l}\text { Capsule surface analysis / } \\
\text { Kapsulu virsmas analize }\end{array}$ & $\begin{array}{c}\text { Quantachrome } \\
\text { Instruments, 2013 }\end{array}$ \\
\hline \multicolumn{2}{|c|}{ Chemical parameters / K̦ìmiskie rādītāji } \\
\hline Total protein / Kopējās olbaltumvielas & AOAC 984.13 \\
\hline
\end{tabular}


Continuation of the table $1 /$ 1. tabulas turpinājums

\begin{tabular}{|c|c|}
\hline $\begin{array}{l}\text { Parameters / } \\
\text { Radītājii }\end{array}$ & $\begin{array}{l}\text { Standards and methods / } \\
\text { Standarti un metodes }\end{array}$ \\
\hline $\begin{array}{l}\text { Total carbohydrates / } \\
\text { Kopējie oglhidrāti, g } 100 \mathrm{~g}^{-1}\end{array}$ & Arapoglou et al., 2009 \\
\hline Dietary fibre / Škiedrvielas, g $100 \mathrm{~g} \mathrm{~g}^{-1}$ & AOAC 985.29 \\
\hline Starch / Ciete, g $100 \mathrm{~g}^{-1}$ & $\begin{array}{c}\text { AOAC 996.11 } \\
\text { AOAC 75-13.01 }\end{array}$ \\
\hline $\begin{array}{l}\text { Glycoalkaloids ( } \alpha \text {-solanine, } \alpha \text {-chaconine), } \\
\text { chlorogenic acid, phenylalanine / } \\
\text { Glikoalkaloīdi ( } \alpha \text {-solanīns, } \alpha \text {-čakonīns), } \\
\text { hlorogénskābe, fenilalanīns, } \mathrm{mg} \mathrm{g}^{-1}\end{array}$ & $\begin{array}{c}\text { LC-HRMS } \\
\text { Lopez-Cobo et al., } 2014\end{array}$ \\
\hline Total lipids / Kopējie lipīdi, g $100 \mathrm{~g} \mathrm{~g}^{-1}$ & AOAC 920.39 \\
\hline Ash / Pelnvielas, g $100 \mathrm{~g}^{-1}$ & ISO 2171: 2010 \\
\hline $\begin{array}{l}\text { Total phenolics / } \\
\text { Kopējie fenoli, mg GAE g }{ }^{-1}\end{array}$ & Jung et al., 2011 \\
\hline $\begin{array}{l}\text { Free radical scavenging activity / } \\
\text { Brīvo radikāḷ saistīsanas spēja, \% }\end{array}$ & Yu et al., 2013 \\
\hline $\begin{array}{l}\text { Dextrose equivalent / } \\
\text { Dekstrozes ekvivalents, DE }\end{array}$ & Lane \& Eynon, 1923 \\
\hline 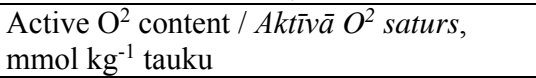 & AOAC 965.33 \\
\hline
\end{tabular}

\section{Statistical analysis}

Data mathematical analysis had been performed with MS Excel $v 16$ and R 3.4.1 softwares, applying a) Dixon's Q test, b) ANOVA, c) Tukey test, and d) Student's t-test. Differences were considered insignificant at $P>0.05$.

\section{RESULTS AND DISCUSSION \\ 1. Evaluation of industrial potato processing by-products (peels)}

After evaluating all available industrial potato processing by-products (IPPB), it had been decided to continue present research on potato peel wastes, that could be divided in three categories: 1) large peel $(4 \pm 1 \mathrm{~cm})$, 2) small peel ( $4 \pm 1 \mathrm{~mm})$, and 3) completely shredded peel. Decision had been based on a stable availability of the source material and possibilities of collection and storage in Latvia. In general, whole under-sized potato tubers also can be added to this category in the future and considered as the same material as potato peels, but with decreased concentration of biologically active compounds (BAC) and increased starch content.

Chemical analysis of collected samples had been conducted and results are presented in the Table 2 . 
Table 2 / 2. tabula

Chemical composition of potato peel samples from three

industrial peeling lines, $\mathbf{g} \mathbf{1 0 0} \mathbf{g}^{-1} \mathbf{d w}$ (Шепелев et al., 2015) /

Triju veidu kartupeḷ rūpnieciskās pārstrādes blakusproduktu

kīmiskais sastāvs, g $100 \mathrm{~g}^{-1} \mathrm{dw}$

\begin{tabular}{|c|c|c|c|c|}
\hline \multirow{2}{*}{$\begin{array}{l}\text { Parameters / } \\
\text { Parametri, }\end{array}$} & \multicolumn{3}{|c|}{ Peel samples / Mizu paraugi } & \multirow{2}{*}{$\begin{array}{c}\text { Theoretical } \\
\text { values / } \\
\text { Teorētiskas } \\
\text { vērtības }\end{array}$} \\
\hline & $\begin{array}{l}\text { Large } \\
\text { peel / } \\
\text { Lielas } \\
\text { mizas }\end{array}$ & $\begin{array}{c}\text { Shredded } \\
\text { peel/ } \\
\text { Sasmalcinātas } \\
\text { mizas }\end{array}$ & $\begin{array}{l}\text { Small } \\
\text { peel / } \\
\text { Mazas } \\
\text { mizas }\end{array}$ & \\
\hline $\begin{array}{l}\text { Ash / } \\
\text { Pelnvielas, g } 100 \mathrm{~g}^{-1} \mathrm{dw}\end{array}$ & $\begin{array}{l}8.1 \pm \\
\pm 0.0 \\
\end{array}$ & $4.3 \pm 0.0$ & $\begin{array}{l}2.8 \pm \\
\pm 0.3\end{array}$ & $\begin{array}{c}7.0 \pm \underset{c, d}{1.0^{a, b}} \\
\end{array}$ \\
\hline $\begin{array}{l}\text { Nitrogen / } \\
\text { Slāpeklis, g } 100 \mathrm{~g}^{-1} \mathrm{dw}\end{array}$ & $\begin{array}{l}2.2 \pm \\
\pm 0.1\end{array}$ & $0.9 \pm 0.2$ & $\begin{array}{l}1.3 \pm \\
\pm 0.2\end{array}$ & $1.3 \pm$ n.a. $^{\mathrm{a}}$ \\
\hline $\begin{array}{l}\text { Protein / } \\
\text { Olbaltumvielas, } \\
\mathrm{g} 100 \mathrm{~g}^{-1} \mathrm{dw}\end{array}$ & $\begin{array}{c}13.6 \pm \\
\pm 0.6\end{array}$ & $5.6 \pm 1.0$ & $\begin{array}{l}8.4 \pm \\
\pm 1.1\end{array}$ & $\begin{array}{c}12.6 \pm 6.4^{\mathrm{a}} \\
\mathrm{b}, \mathrm{c}, \mathrm{d}\end{array}$ \\
\hline $\begin{array}{l}\text { Total carbohydrates / } \\
\text { Oglhidrāti, kopā, t.sk. } \\
\text { g } 100 \mathrm{~g}^{-1} \mathrm{dw}\end{array}$ & $\begin{array}{l}77.7 \pm \\
\pm 0.7\end{array}$ & $89.4 \pm 1.1$ & $\begin{array}{c}80.7 \pm \\
\pm 1.7\end{array}$ & $\begin{array}{c}66.6 \pm 11.2 \\
\text { a, b, d }\end{array}$ \\
\hline $\begin{array}{l}\text { total fibre / } \\
\text { škiedrvielas, g } 100 \mathrm{~g}^{-1} \mathrm{dw}\end{array}$ & $\begin{array}{c}16.1 \pm \\
\pm 0.1 \\
\end{array}$ & $26.0 \pm 0.7$ & $\begin{array}{l}30.1 \pm \\
\pm 0.9 \\
\end{array}$ & $\begin{array}{c}23.8 \pm 12.5 \\
\text { a, d } \\
\end{array}$ \\
\hline $\begin{array}{l}\text { total starch / } \\
\text { ciete, kopā }, \mathrm{g} 100 \mathrm{~g}^{-1} \mathrm{dw}\end{array}$ & $\begin{array}{l}64.3 \pm \\
\pm \text { n.a. }\end{array}$ & $68.0 \pm$ n.a. & $\begin{array}{l}57.2 \pm \\
\pm \text { n.a. }\end{array}$ & $\begin{array}{c}50.6 \pm 23.0 \\
\text { a, b, c, d }\end{array}$ \\
\hline $\begin{array}{l}\text { Total lipids / } \\
\text { Kopéjie lipīdi, g } 100 \mathrm{~g}^{-1} \mathrm{dw}\end{array}$ & $\begin{array}{l}0.6 \pm \\
\pm 0.1 \\
\end{array}$ & $0.7 \pm 0.1$ & $\begin{array}{l}8.1 \pm \\
\pm 0.3 \\
\end{array}$ & $1.6 \pm \underset{d}{1.4^{a, b},}$ \\
\hline
\end{tabular}

n.a. - not applicable / nav piemérojams; dw - dry weight / sausna. Theoretical value sources / Atsauces uz teorētiskām vērtībām: a) Arapoglou et al., 2009;

b) Liang et al., 2014; c) Mahmood et al., 1998; d) USDA, 2018.

It should be emphasized that all peel samples were collected from the actual potato processing lines and had been formed from different potato varieties, and each collected sample usually had been represented as a mix of different genotypes. As a result, these data had been compared to the average numbers reported in the literature.

Samples, formed by small peels, showed four times higher lipid content than

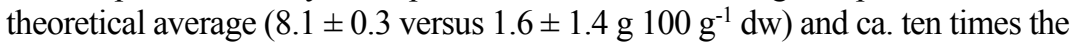

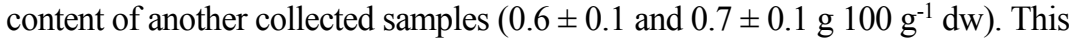
fact represents a by-product collection problem in the big processing facility, where waste collection systems are closed and several different waste streams are mixed. In the present case, peel samples were mixed with a part of the disposed final product - fried potato chips.

Content of the remaining chemical compounds were within the theoretical values, with minor fluctuations. It was reported previously that recovered 
proteins from potato peels are of a superior quality compared to the most vegetable proteins, but their discoloration stigma constitutes a major setback in its utilization in the food systems (Mu et al., 2009), and large amount of work already had been done on protein recovery and oxidative browning inhibition (Arogundade \& Mu, 2012; Mu et al., 2009; Schmidt et al., 2018). Taking in consideration the popularity of industrial vegetable processing byproducts application as a dietary fibre source in food production, it had been decided to concentrate further studies on biologically active compound and starch recovery and application in food production.

\section{Extractable biologically active compound stability in potato processing by-products}

As had been described previously, potato peel biologically active compound profile if highly dependent on many factors, including potato variety, storage time and conditions, season, and cultivation conditions. In addition, usually each potato processing company (especially in Latvia) is using their own variety or several varieties at the same time. Because of that, and fact that BAC profiles of different potatoes had been studied previously in great detail in the literature, present work is focused on the BAC in general.

Results show that during the storage at uncontrolled conditions phenols are more stable in the larger peel samples (large and small peels) than in the finely shredded peel samples. During the first minutes after peeling, peel samples showed signs of the browning, which indicated a presence of the fermentative reactions. Vámos-Vigyázó (1981) had reported that polyphenol oxidase (PPO) in potatoes catalyses the conversion of monophenols to o-diphenols and o-dihydroxyphenols to o-quinones. After that, quinone products can polymerize and react with amino acid groups of cellular proteins that will lead to brown pigment appearing. In addition, Thygesen et al. (1995) showed that the highest activity of the PPO is in the subepidermal or outer cortex layer, in distance of 1.5-2.0 $\mathrm{mm}$ from the skin. Exactly the layer that is taken off by abrasion peeling methods that are applied in the Latvian potato processing facilities.

Fig. 7 shows the effect of the storage time on the total phenolic content in the samples. No significant difference was observed between large and small peels. Total phenolic amount was stable during the first two days of storage and showed a significant decline on the third, by $40 \%$ comparing to the average of the previous days. Meanwhile, in finely shredded peel phenol content show significant decrease already on the second day of the storage, by $66 \%$. Difference in the peel sample physical conditions and total phenolic content indicates that the phenols in finely shredded peel samples are more easily exposed to the fermentative and microbial degradation, while in the 
larger peel samples the whole structure of the cell can express a protective effect.

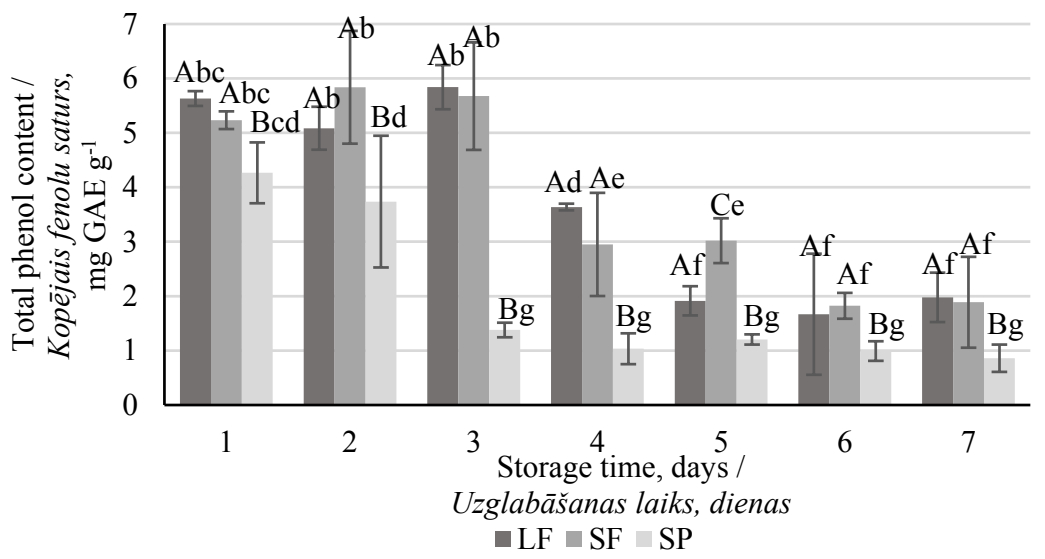

Fig. 7. Effect of the storage time at uncontrolled conditions on the total phenolic content in the potato peel samples (Shepelev et al., 2016) / 7. att. Uzglabāšanas laika ietekme uz kopējo fenolu saturu kartupelı mizu paraugos

LF - large peel / lielas mizas; SF - small peel / mazas mizas; SP - shredded peel / sasmalcinātas mizas. The data is presented as a mean $(\mathrm{n}=9)$ / Dati uzrādìti $k \bar{a}$ vidèjās vērtības $(\mathrm{n}=9)$. Similar lowercase letters indicate no significant difference among samples $(P>0.05)$ / Vienādi mazie burti apzīmē paraugus bez būtiskām atškirīibām nedēlas garuma $\bar{a}(P>0.05)$. Similar uppercase letters indicate no significant difference among peel types within each day separately $(P>0.05) /$ Vienādi lielie burti apzīmē paraugus bez bütiskām atšksirībām starp paraugiem vienas dienas ietvaros $(P>0.05)$.

Fig. 8 shows the effect of the storage time on the free radical scavenging activity of the potato peel extracts at uncontrolled conditions. After the first day of the storage all three types of PP samples showed no significant changes in the free radical scavenging activity, but on the second day finely shredded peel had lost $97 \%$ of its free radical scavenging activity while activity of the larger peel samples stayed at the previous level. Only on the third day of storage, larger peel samples started to show the first significant decline in its free radical scavenging activity.

It can be observed (Fig. 9) that correlation between total phenolic content and free radical scavenging have a polynomic character. It is well known that chlorogenic acid and caffeic acid are two of the main phenols in potatoes (Solanum tuberosum L.) and both act as antioxidants (Al-Weshahy \& Rao, 2009; Habeebullah et al., 2010; Mattila \& Hellström, 2007; Sánchez Maldonado et al., 2014; Singh \& Saldaña, 2011; Wu et al., 2012b). 

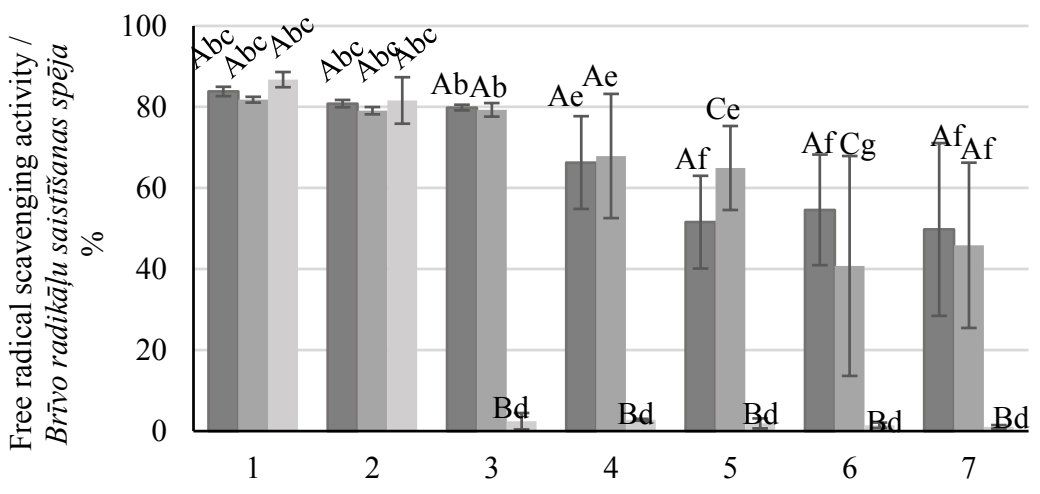

Storage time, days / Uzglabāšanas laiks, dienas

$\square \mathrm{LF} \backsim \mathrm{SF} \mathrm{SP}$

Fig. 8. Effect of the storage time at uncontrolled conditions on the free radical scavenging activity of the potato peel extracts

(Shepelev et al., 2016) /

8. att. Uzglabāšsanas laika ietekme uz kartupeḷu mizu ekstrakta brīvo radikālu saistīšanas spēju

LF - large peel / lielas mizas; SF - small peel / mazas mizas; SP - shredded peel / sasmalcinātas mizas. The data is presented as a mean $(\mathrm{n}=9)$ / Dati uzrādìti $k \bar{a}$ vidèjās vērtības $(n=9)$. Similar lowercase letters indicate no significant difference among samples $(\mathrm{P}>0.05)$ / Vienādi mazie burti apzīmē paraugus bez būtiskām atškirībām nedēḷas garumā $(P>0.05)$. Similar uppercase letters indicate no significant difference among peel types within each day separately $(\mathrm{P}>0.05) /$ Vienādi lielie burti apzīmē paraugus bez būtiskām atškirībām starp paraugiem vienas dienas ietvaros $(P>0.05)$.

Chlorogenic acid is an ester of the caffeic and (-)-quinic acids and it is reported that esterification of caffeic acid by a sugar moiety decreases its antioxidant activity (Cuvelier et al., 1992). Studies show that chlorogenic acid is less effective as an antioxidant than caffeic acid in lard and stripped corn oils (Chen \& Ho, 1997). At concentrations of 0.5, 1.0 and $2.0 \mathrm{mM}$, caffeic acid was more effective against alkoxyl radical scavenging in sunflower oil (Milic et al., 1998) and better inhibited lipid oxidation in fish muscles (Medina et al., 2007). Contrary, it is possible that the binding of the quinic acid to caffeic acid increases antioxidant activity and decreases hydrogen peroxide and DPPH $^{*}$ scavenging activities (Sroka \& Cisowski, 2003).

Marinova et al. (2009) had found that difference in the antioxidative activity of chlorogenic and caffeic acids during antioxidation of triacylglycerols of sunflower oil strongly depends on their concentrations and 
at $2.8 \times 10^{-4} \mathrm{M}$ both acids show equal effectiveness and strength, but at concentrations above $10 \times 10^{-4} \mathrm{M}$ caffeic acid is much more effective and stronger inhibitor.

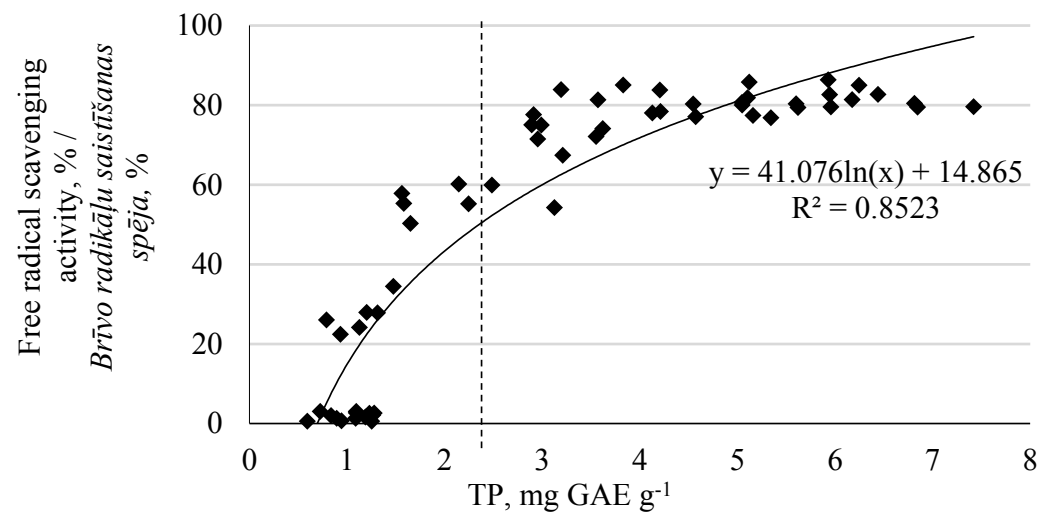

Fig 9. Correlation between total phenol content and the free radical scavenging activity of the potato peel extract (Shepelev et al., 2016) / 9. att. Korelācija starp kartupeḷ mizu ekstrakta kopējo fenolu saturu un brīvo radikālu saistǐšanas spēju

$\mathrm{TP}$ - total phenolics / kopējie fenoli; GAE - gallic acid equivalent / galluskābes ekvivalents. The data is presented as a mean $(\mathrm{n}=9)$ / Dati uzrādīti kā vidējās vērtības $(n=9)$.

Usually, chlorogenic acid is the most abundant in PP, but when PP are stored at room temperature or in light, chlorogenic acid degrades and transforms into caffeic and quinic acids (Sotillo et al., 1994). Based on the collected data it can be assumed, that after peeling there were big amounts of chlorogenic acid in the samples. When total amount of phenolics started to decrease, chlorogenic acid degraded and caffeic acid was released in a sufficient amount to hold free radical scavenging activity of the extract on the high level till the total phenolic content did not decrease below $3.0 \mathrm{mg}$ GAE $\mathrm{g}^{-1}$ (Fig. 9) when caffeic acid concentration became too low.

Dynamics of the chlorogenic acid and phenylalanine concentration decrease are shown in Fig. 10. Samples, consisting of large and small peels, showed very similar tendency, while in the shredded peel sample chlorogenic acid was almost absent already after peeling. It is a result of complete destruction of potato peel cells, when plant secondary metabolites start to inhibit oxidative stress and associated molecular damage via several possible reaction paths that are described in detail elsewhere (Fifen et al., 2011; Galano et al., 2016; Tošović et al., 2017). 

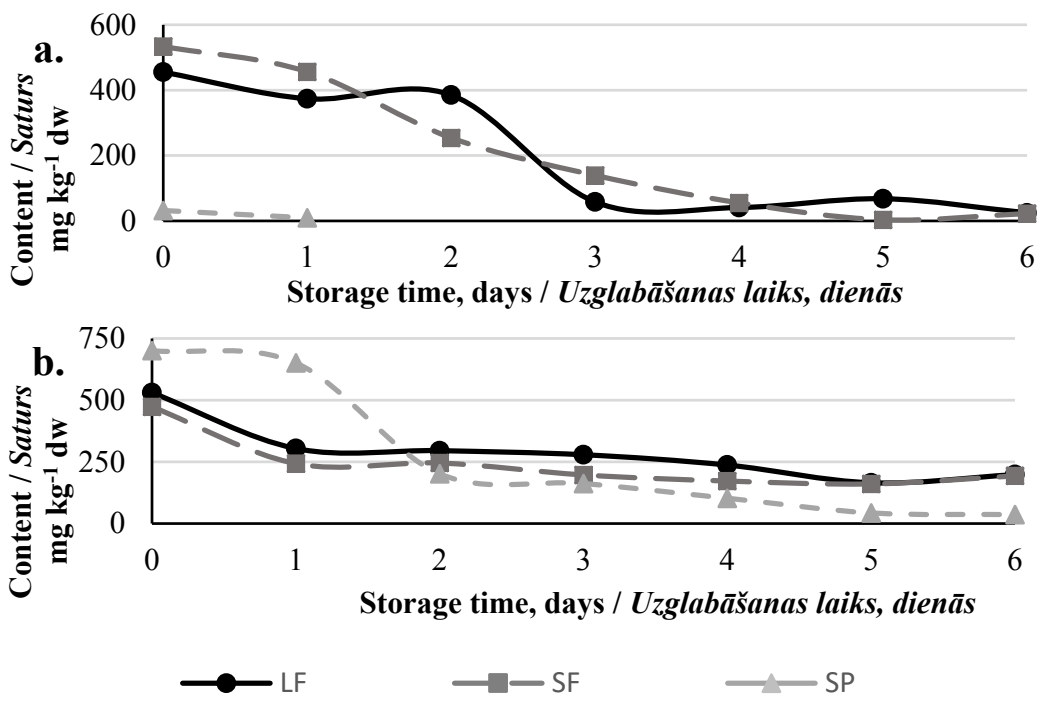

Fig 10. Chlorogenic acid (a) and phenylalanine (b) degradation in potato peel samples during the storage at ambient conditions / 10. att. Hlorogēnskābes (a) un fenilalanīna (b) noārdīšanās dinamikas kartupeḷu mizu paraugos to uzglabāšanas laikā nekontrolējamos apstākḷos $\mathrm{LF}$ - large peel / lielas mizas; SF - small peel / mazas mizas; SP - shredded peel / sasmalcinātas mizas; $\mathrm{dw}$ - dry weight / sausna.

The data is presented as a mean $(\mathrm{n}=6)$ / Dati uzrādīti kā vidējās vêrtības $(n=6)$.

It can be seen that chlorogenic acid concentration decreased in samples, which contained whole cells (large and small peels), was slower during the first 1-2 days of storage, with further rapid increase in the degradation rate. At the same time, the phenylalanine concentration decrease was the most active during the same observation time, and was more linear in the further days of storage. As a result, it could be assumed that during the first days of storage, chlorogenic acid synthesis from phenylalanine could be still active. In the further days, another reaction components and catalysts could become absent or inactive and stop the reaction path. In case of shredded peel, where chlorogenic acid is practically absent, phenylalanine content started to decrease only on the third day of storage. Based on the rapid decrease rates in this case, it could be a result of microbial activity.

The degradation graphs of two glycoalkaloid compounds present in potato peel during six days of storage are shown in Fig. 11. 

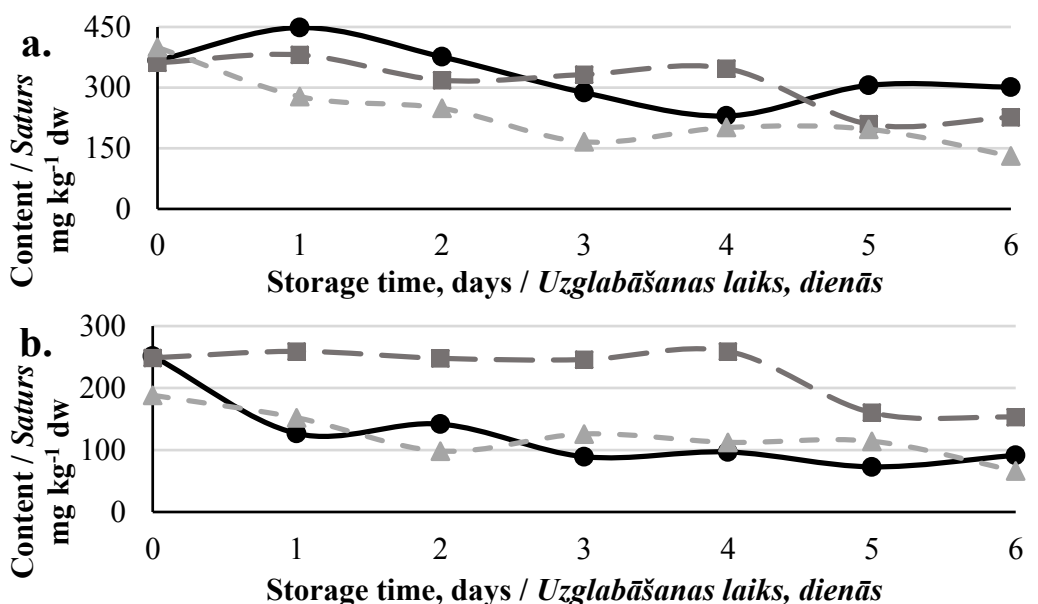

Storage time, days / Uzglabāšanas laiks, dienās
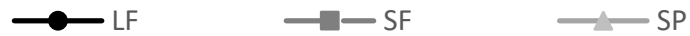

Fig. 11. $\alpha$-solanine (a) and $\alpha$-chaconine (b) degradation in potato peel samples during the storage at ambient conditions /

11. att. a-solanīna (a) un a-čakonīna (b) degradācijas dinamika kartupeḷu mizu paraugos to uzglabāšanas laikā nekontrolējamos apstākḷos

$\mathrm{LF}$ - large peel / lielas mizas; SF - small peel / mazas mizas; $\mathrm{SP}$ - shredded peel / sasmalcinātas mizas; $\mathrm{dw}$ - dry weight / sausna.

The data is presented as a mean $(\mathrm{n}=6)$ / Dati uzrādìti kā vidèjās vêrtības $(n=6)$.

Linear approximation showed that $\alpha$-solanine degradation rates were the slowest in the bigger size peel. Similar results, but with a little bigger rate, showed small peel. In the shredded peel samples all biologically active compounds (including glycoalkaloids, chlorogenic acid, and phenylalanine) were more exposed to the environmental impacts and enzymes that were released as a result of a cell disruption, and degradation rates of any identified compound was higher in the shredded sample. It is important to mention that, during the storage at ambient conditions, some light beams or reflections form the walls, sealing, or surrounding objects could have reached samples causing additional glycoalkaloid formation. This fact could also explain the increase in the $\alpha$-solanine content on the third and fourth days of storage. As a result, it could be concluded that potato peel by-products should be stored in the dark if there are whole cells left and formation of glycoalkaloids is not acceptable. 


\section{Comparison of spray-and freeze drying technologies for gallic acid microencapsulation}

To focus on the encapsulation technologies and minimize possible variables, gallic acid had been used for several further experiments as a model water soluble phenolic compound. The efficiencies of GA encapsulation with low DE hydrolysed potato starch as a wall material using freeze-drying (FD) and spray-drying (SD) methods is presented in Fig. 12. Statistical analysis showed no significant difference of efficiencies of processes carried out by both methods $(P>0.05)$. It was possible to achieve encapsulation efficiency of $72 \pm 7 \%$ for the FD and $77 \pm 7 \%$ for SD samples.

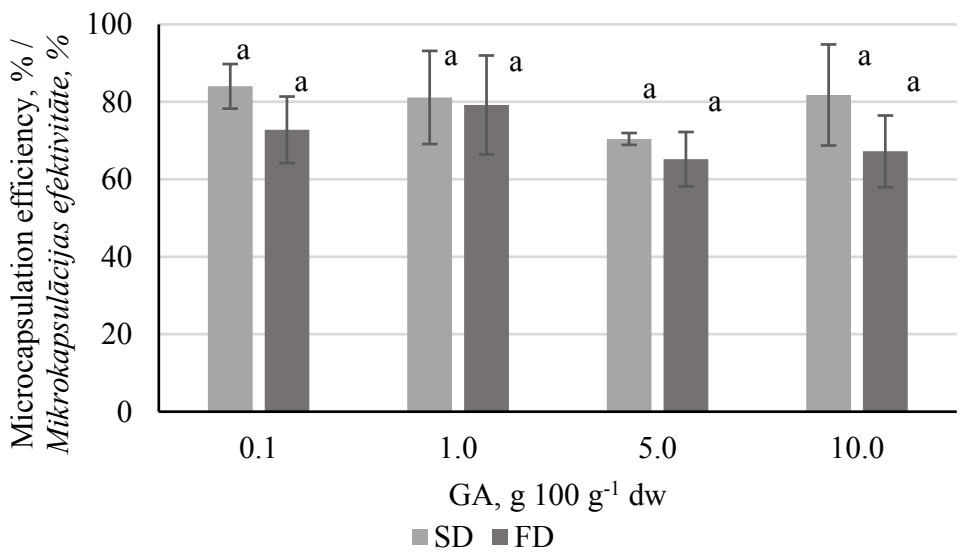

Fig. 12. Gallic acid (GA) encapsulation efficiencies using spray-drying (SD) and freeze-drying (FD) technologies with low dextrose equivalent

(DE 2) starch as a wall material (Sepelevs et al., 2018)/

12. att. Galluskābes (GA) mikrokapsuläcijas efektivitāte, izmantojot izsmidzināšanas un liofilizācijas mikrokapsulācijas metodes

GA - gallic acid content in samples / galluskābes saturs paraugos; dw - dry weight / sausna. The data is presented as a mean $(\mathrm{n}=9)$ / Dati uzrādìti kā vidējās vêrtības $(n=9)$. Similar letters indicate no significant difference among samples $(P>0.05) /$

Vienādi burti apzīmē paraugus bez bütiskām atšķirìbām $(P>0.05)$.

Visual appearance of the prepared SD and FD microcapsules can be observed in Fig. 13. The differences in the surface morphology are dependent on encapsulation technology, operation conditions and parameters.

SD samples had a spherical shape form due to the specifics of spray drying process; as infeed liquid sample was atomized in the drying chamber. Due to the solvent surface tension, while falling through the chamber round droplets were formed and those were dried by air forming spherical capsules. At the same time, 
FD particles appeared in an irregular shapeless forms. They were monolithic and varied highly in shape and size. Form and inner structure of FD particles were also determined by encapsulation process. As whole liquid sample was rapidly frozen, GA was fixed in the wall material matrix. After freeze drying, matrix was crushed and, as a result, shapeless particles were produced.
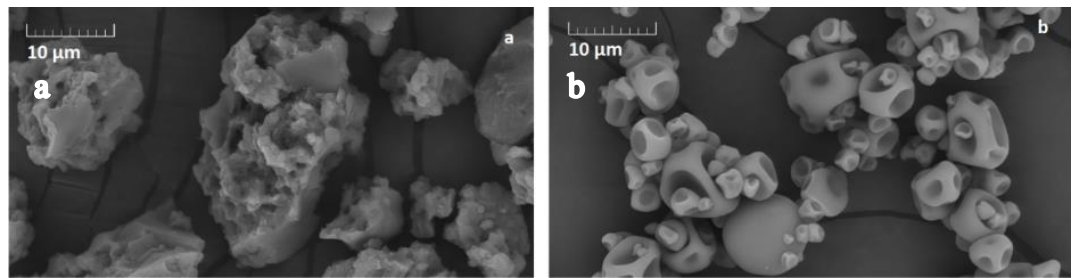

Fig. 13. Freeze-dried (a) and spray-dried (b) capsules under the electron microscope (Sepelevs et al., 2018)/

13. att. Kapsulas, pagatavotas ar liofilizäcijas (a) un izsmidzināšanas kaltēšanas (b) mikrokapsulācijas paņēmieniem, kapsulu attēls elektronmikroskopā

Table 3 shows capsule surface parameters obtained by Barrett-JoynerHalenda (BJH) nitrogen desorption method and Dubinin-Radushkevich (DR) micropore analysis. FD samples show bigger cumulative desorption surface area (from 0.632 to $1.225 \mathrm{~m}^{2} \mathrm{~g}^{-1}$ ) and bigger cumulative desorption pore volumes (from $2.4 \times 10^{-3}$ to $9.5 \times 10-3 \mathrm{~cm}^{3} \mathrm{~g}^{-1}$ ) than $\mathrm{SD}$ samples (from $0.472 \times 10^{-3}$ to $1.296 \times 10^{-3} \mathrm{~cm}^{2} \mathrm{~g}^{-1}$ and from $1.2 \times 10^{-3}$ to $4.9 \times 10^{-3} \mathrm{~cm}^{3} \mathrm{~g}^{-1}$ respectively). DR method shows micropore presence on the FD capsule surface with average micropore surface area from 1.028 to $2.229 \mathrm{~m}^{2} \mathrm{~g}^{-1}$, that is smaller than that of the SD samples (from 1.108 to $2.374 \mathrm{~m}^{2} \mathrm{~g}^{-1}$ ), which results in the bigger micropore volume in the SD samples.

Table 3 / 3. tabula

Capsule surface analysis by Brunauer-Emmett-Teller (BET) method and t-method (Sepelevs et al., 2018) /

Kapsulu virsmas analize ar Brunauera-Ennetta-Tellera (BET) metodi un t-metodi

\begin{tabular}{|c|c|c|c|c|c|c|c|}
\hline \multirow[b]{2}{*}{ 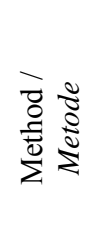 } & \multirow[b]{2}{*}{ 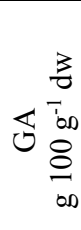 } & \multicolumn{3}{|c|}{ BJH method / BJH metode } & \multicolumn{3}{|c|}{ DR method / DR metode } \\
\hline & & 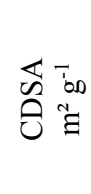 & 己. & $\begin{array}{l}\Xi \\
\hat{\Xi}\end{array}$ & 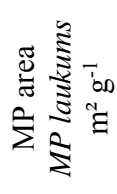 & 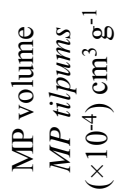 & 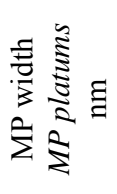 \\
\hline \multirow[t]{2}{*}{ SD } & & 0.929 & 2.4 & 3.1 & 1.533 & 5. & 2.571 \\
\hline & 0.1 & 0.472 & 1.2 & 4.4 & 1.108 & 3.9 & 2.664 \\
\hline
\end{tabular}


Continuation of the table 3. / 3. tabulas turpinäjums

\begin{tabular}{|c|c|c|c|c|c|c|c|}
\hline \multirow[b]{2}{*}{ 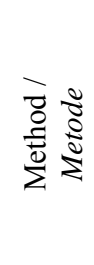 } & \multirow[b]{2}{*}{$\mho_{0}^{\frac{3}{8}}$} & \multicolumn{3}{|c|}{$\begin{array}{l}\mathrm{BJH} \text { method / BJH } \\
\text { metode }\end{array}$} & \multicolumn{3}{|c|}{ DR method / DR metode } \\
\hline & & 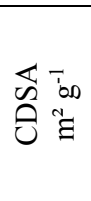 & 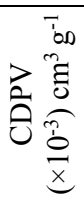 & 章 & 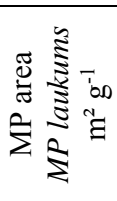 & 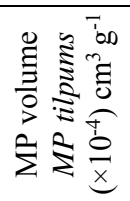 & 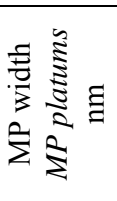 \\
\hline \multirow[t]{3}{*}{ SD } & 1.0 & 0.779 & 3.1 & 3.1 & 2.116 & 7.5 & 2.679 \\
\hline & 5.0 & 1.296 & 2.6 & 3.6 & 2.374 & 8.4 & 2.756 \\
\hline & 10.0 & 0.896 & 4.9 & 3.2 & 2.032 & 7.2 & 2.673 \\
\hline \multirow[t]{5}{*}{ FD } & n.a. & 0.632 & 2.7 & 3.1 & 1.028 & 3.7 & 2.677 \\
\hline & 0.1 & 1.053 & 9.5 & 3.0 & 1.968 & 7.0 & 2.682 \\
\hline & 1.0 & 1.021 & 9.3 & 3.3 & 1.873 & 6.7 & 2.891 \\
\hline & 5.0 & 1.225 & 3.1 & 3.1 & 2.229 & 7.9 & 2.843 \\
\hline & 10.0 & 1.122 & 2.4 & 3.0 & 1.648 & 5.9 & 2.915 \\
\hline
\end{tabular}

GA - gallic acid content in samples / galluskābes saturs paraugos; dw - dry weight

/ sausna; CDSA - cumulative desorption surface area / kumulatīvs desorbcijas virsmas laukums; CDPV - cumulative desorption pore volume / kumulatīvs desorbcijas poru tilpums; DPD - desorption pore diameter / desorbcijas poru diametrs; SD - spray-drying / izsmidzināšanas kalte; FD - freeze-drying / liofilizācija; MP - micropore / mikroporas.

From another side, in case of dealing with high-value thermo-sensitive raw material, FD is a great preservation method that is more economically efficient for long storage in comparison with freezing and storage at negative temperatures, that requires even bigger energy consumptions (Lorentzen, 1979).

\section{Water soluble phenolic compound encapsulation in the multiple layer capsule}

For water soluble compound, three phase encapsulation system (solid lipid core, containing water soluble phenolic compound, surrounded with modified starch shell wall) had been developed in a single spray drying process. It had been designed as an alternative for the multi stage encapsulation technology that consists of core compound encapsulation in the solid shell/matrix with further overlay with an additional wall material. To increase resistance of the outer carbohydrate layer, part of the modified starch (MS) had been converted to the resistant starch (RS) (Dimantov et al., 2004; Eerlingen et al., 1993; Janaswamy, 2014) by prior autoclaving MS at $121 \pm 1{ }^{\circ} \mathrm{C}$ in excess water with further incubation at $22 \pm 2{ }^{\circ} \mathrm{C}, 68 \pm 2{ }^{\circ} \mathrm{C}$, and $100 \pm 2^{\circ} \mathrm{C}$ (Eerlingen et al., 1993). 
In the produced capsules, GA was approximately evenly distributed between core and shell fractions, with little remains on the capsule surface (Fig. 14). It is a result of GA diffusion during $\mathrm{O} / \mathrm{W}$ emulsion preparation, when $\mathrm{O}$ phase was mixed with $\mathrm{W}$ right before mixture feeding into the spraydryer. It is possible that increase in PGPR concentration or addition of another emulsifier could cause better system stabilization and decrease diffusion and increase GA content in the lipid phase. In this case, bigger portion of lipid phase would be concentrated on the $\mathrm{O} / \mathrm{W}$ phase surface, blocking GA migration by stronger hydrophilic polarity.

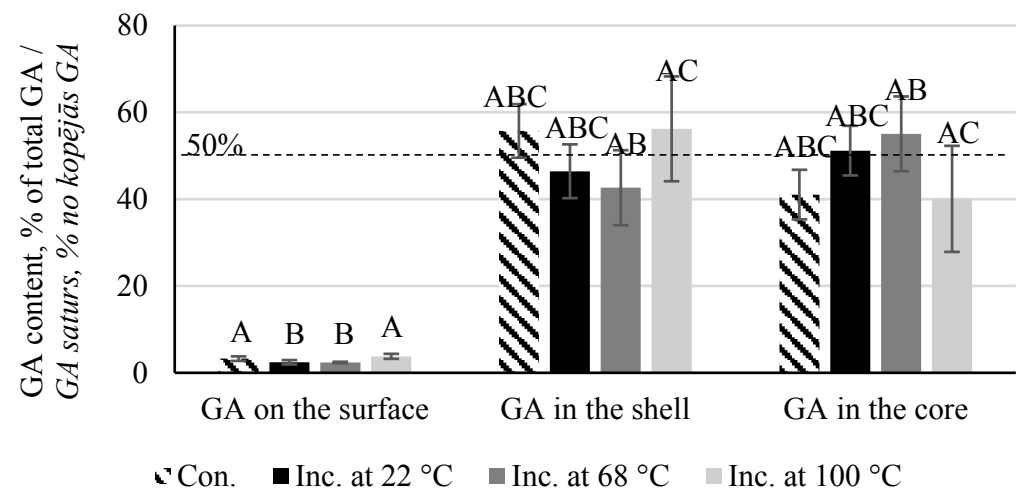

Fig 14. Distribution of gallic acid in different capsule fractions (Sepelevs \& Reineccius, 2018) /

\section{4. att. Galluskābes sadalījums starp kapsulu frakcijām}

GA - gallic acid / galluskābe; Con. - control / kontrole; Inc. - incubation / inkubācija. The data is presented as a mean $(\mathrm{n}=9)$ / Dati uzrādīti kā vidējās verrtības $(n=9)$. Similar letters indicate no significant difference among samples of the same fraction $(P>0.05)$ / Vienādi mazie burti apzīme paraugus bez būtiskām atškirī̄bām vienas frakcijas ietvaros $(P>0.05)$.

Holser (2013) showed that ferulic acid, another phenolic compound with antioxidative properties, encapsulated in lipid matrix capsules was stable during 3 months storage at ambient conditions. In another study, lipid nanoparticles placed in water were able to stabilise (-)-epigallocatechin-3-gallate during 4 weeks period while (-)-epigallocatechin-3-gallate solubilized in water exhibited $100 \%$ degradation within 4 hours period (Barras et al., 2009). Solid lipid fraction, used in the present study, had a melting point approximately of $50{ }^{\circ} \mathrm{C}$. This allows concluding that $\mathrm{GA}$ in produced capsules is well protected from environmental factors. It is not only encapsulated in the hydrophobic core, but also surrounded by additional MS 
shell that should protect melted lipids from leakage and capsule agglomeration, in case of capsule storage at temperature that exceeds $50{ }^{\circ} \mathrm{C}$.

Fig. 14 shows that big part of total encapsulated GA had been diffused into the water phase during sample preparation period and was fixed in the MS matrix. In the present study used commercial MS is known for its great encapsulation properties and ability to mask undesirable odours and flavours of encapsulated substance, including phenolics (Spinelli et al., 2016). This means that GA in the shell can be considered as shielded, till capsule will come in contact with aqueous phase that will dilute shell wall material or cause GA diffusion from MS phase into the surrounding aqueous phase.

Based on the discussed issues, it can be assumed that produced capsules could be added to different types of food products (ground meat or fish, or dough) in order to release phenolics from the shell wall to the surrounding media. Released phenolics could serve as antioxidants for the food product itself. If there will be no temperature rises combined with intensive mixing that would break integrity of lipid core (as in sausage production), lipid phase phenolics will remain fixed in the lipid phase and protected till will come into the human digestive system. Wada \& Fang (1992) had shown that phenolics are able to inhibit polyunsaturated fatty acid oxidation in frozen-crushed bonito meat. In whole and ground meat products, phenolics were effective in retarding rancid odour and flavour, and colour changes (Shah et al., 2014). Better retention of colour and protection of lipids against peroxidation due to the addition of phenols had been observed also in irradiated meats (Kanatt et al., 2005). Similar results were acquired for minced horse mackerel (Farvin et al., 2012). In case of human nutrition, phenolics are known to have multiple positive effects on the health by alleviating oxidative stress (Singh \& Rajini, 2004, 2008).

Only small percentage of total GA had been exposed on the capsule surface: $2.4 \pm 0.5 \%$ for samples incubated at $22{ }^{\circ} \mathrm{C}, 2.3 \pm 0.2 \%$ for samples incubated at $68{ }^{\circ} \mathrm{C}, 3.8 \pm 0.6 \%$ for samples incubated at $100{ }^{\circ} \mathrm{C}$, against $3.3 \pm 0.5 \%$ for the control sample. These amounts can be considered as permanent losses, bringing the total encapsulation efficiency to $97.1 \pm 0.4 \%$.

It can be concluded that produced capsules can be considered as stable and can be stored at ambient conditions. As an example, in case of uncontrolled temperature increase, capsule shell will maintain its integrity and particles will not stick together lowering powdered product quality, as it can happen during capsule transportation in the summer time without specialized cooling equipment. As starch is not a reactive material, capsules do not require specific storage conditions and packaging material, except protection from the excess moisture to prevent dilution of the shell and GA diffusion/dissolution. This minimises storage expenses and overall potential price of the produced capsules. 


\section{Simultaneous phenolic compound and carbohydrate extraction and further encapsulation}

Previously developed encapsulation method is well suitable for multiple phase capsule production in the one single spray-drying process. Although, it had been decided for the industrial purposes it would be a big advantage if both, BAC and encapsulation material itself could be derived from the same peel material simultaneously. As a result, the main goal of the present research stage was to develop a compact, easy, and fast potato peel recycling method for encapsulated BAC production), applying only basic equipment, if possible (Fig. 15).

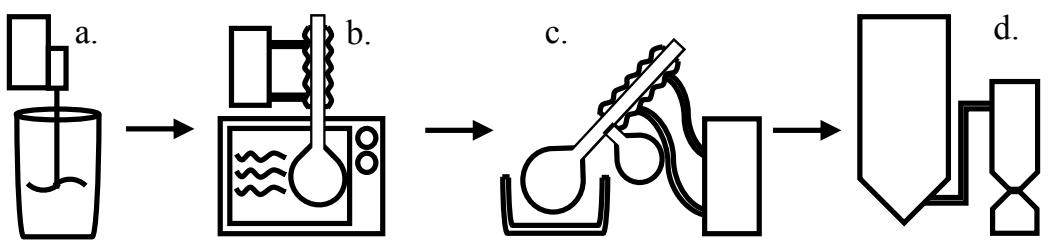

Fig. 15. Necessary equipment for the simultaneous biologically active compound extraction and microencapsulation / 15. att. Nepieciešamās iekārtas biologiski akt̄̄vo vielu ekstrakcijai un mikrokapsulācijai

a. - blender / blenderis; b. - microwave assisted extractor / mikroviln, veicināta ekstrakcija; c. - vacuum evaporator / vakuuma ietvaicētājs; d. - spray-dryer / izsmidzināšanas kalte.

Developed method implies that potato peels can be processed without any specific preparation process, as, for example, drying or sorting. The only prerequisite, derived from the acquired results in previous chapters of present work, is that peels should contain whole cells (that will ensure bigger BAC yield).

For the present research, it had been decided to use samples from abrasion peeling lines, as steam peeling technologies were not available in Latvia at the moment of these studies due to the big potato processing amounts that steam-peeling machinery requires. In addition, there work was targeted to Latvian manufacturing conditions.

Developed extraction-encapsulation process consists of five actual steps:

1. Potato peel collection directly from the processing line to ensure minimal contamination.

2. Mixing collected peels with a solvent $(60 \% \mathrm{EtOH})$ and homogenisation. Present stage also implies a first extraction stage - conventional extraction, when first BAC and carbohydrates start to diffuse into the 
solvent. It is important to achieve maximal cell shredding to ensure better solvent penetration into the ground mass. In the present study, it was decided to use solvent-to-peel ratio of $10: 1(\mathrm{~mL}: \mathrm{g})$.

3. The main extraction step. In present study, combinations of two extraction methods (microwave assisted extraction and ultrasound treatment) were tested, to ensure the best ratio between the extraction yield and applied energy consumption.

Extraction had been performed for 5, 10, 15, and 20 minutes. Fig. 16 shows the BAC extraction yield, and Fig. 17 shows free radical scavenging activity of extracts depending on the extraction time and method.

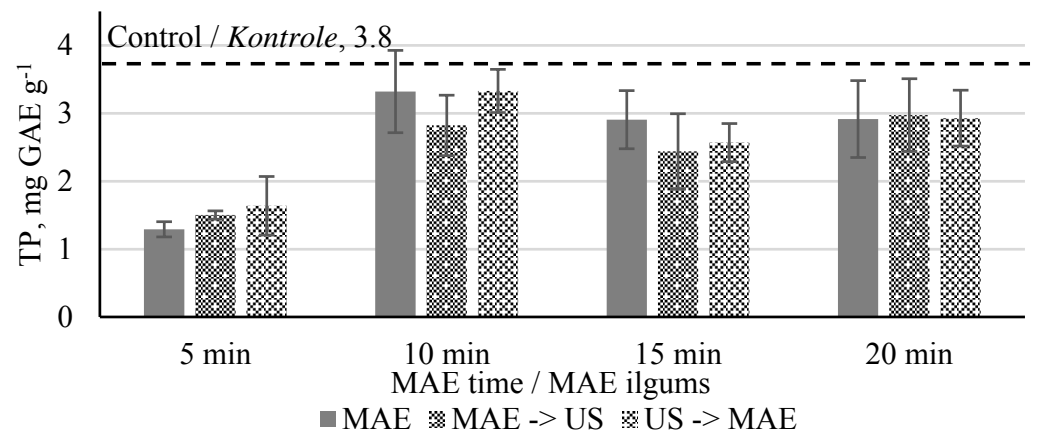

Fig. 16. Phenolic compound extraction yield depending on the extraction method /

\section{6. att. Ekstrahēto fenolu iznākums atkarībā no ekstrakcijas metodes}

$\mathrm{TP}$ - total phenolics / kopējie fenoli; GAE - gallic acid equivalent / galluskābes ekvivalents; MAE - microwave assisted extraction / mikrovilnu veicināta ekstrakcija; MAE -> US - microwave assisted extracting with following 5 min of ultrasound treatment / mikrovilnu veicināta ekstrakcija ar sekojošu 5 min ultraskanas iedarbību; US -> MAE - 5 min of ultrasound treatment with following microwave assisted extraction / 5 min ultraskaņas iedarbïba ar sekojošu mikrovilnnu veicinātu ekstrakciju. The data is presented as a mean $(\mathrm{n}=9) /$

Dati uzrādīti kā vidējās vērtības $(n=9)$.

It can be seen from the Fig. 16 that the shortest extraction time of $5 \mathrm{~min}$ gave the lowest BAC yield in the final extracts. Samples with the extraction time of 10 min showed the higher BAC extraction yields. Rest of the samples, extracted at 15 and $20 \mathrm{~min}$, showed lower results compared to $10 \mathrm{~min}$, bet higher than samples extracted during the 5 min period. Incorporation of the ultrasound treatment gave a positive result only to the samples with $5 \mathrm{~min}$ MAE treatment. Acquired results are matching previously reported data $(\mathrm{Wu}$ et al., 2012a).

As shown in Fig. 17, samples extracted for $10 \mathrm{~min}$ period have also the highest free radical scavenging activity. Furthermore, free radical scavenging 
activity drops when additional ultrasound treatment is used. This fact could suggest that completely extracted phenolic compounds (as shown in Fig. 16) could undergo degradation, as ultrasound treatment had been combined with higher temperatures. Advanced research on different extraction method combination should be conducted to give a more precise conclusion. Regarding to the present research, based on the acquired results it was decided to omit ultrasound incorporation in the extraction process and use only MAE for the further extraction purposes.

4. After extraction, acquired extracts were concentrated in the vacuum evaporation equipment to achieve two main goals:

a. recover solvent for the repeated extraction (ethanol concentration could be adjusted based on the solvent density);

b. decrease volume of samples to decrease energy and time consumption for the next stage - spray-drying (encapsulation).

After the concentration, samples were stored under the vacuum to decrease phenolic compound reactions with radicals and oxygen, present in the air.

5. The encapsulation of produced extracts via spray-drying process. Main idea of the present step is that there will be both: BAC and short chain carbohydrates dissolved in the extract samples.

It had been planned that multiple types of encapsulation could take place in produced capsules. First of all, formation of the matrix type capsule should occur, as both core and wall materials are water soluble and should form homogeneous structures. Low molecular weight sugars should form a solid shell wall that should prevent oxygen diffusion inside the capsule and active compound oxidation. Secondly, formation of amylose inclusion complexes could be possible, when BAC will be incorporated into the amylose chain network.

Theoretically, there could be an additional option for encapsulated BAC application - introduce produced capsules as a separate specialized wall material for another valuable compound encapsulation, to ensure the protection of encapsulated materials against oxidation. For example, it could be used for unsaturated oil encapsulation, where incorporated in the starch shell wall phenolic compounds could serve as an additional oxygen barrier. Additionally, it had been reported that some of the water soluble polysaccharides (no specification reported) from potato peels have good water holding abilities, fat binding capacity, foaming properties (due to the presence of some protein remains), emulsification stability, and possess a natural antioxidant abilities (Jeddou et al., 2016). As a result, it could be concluded that produced mixture of simultaneously extracted BAC and carbohydrates have a potential to serve as a wall material, for example, for the pharmacological use, where active compound preservation plays a critical role and application of more expensive wall materials is a common practice. 


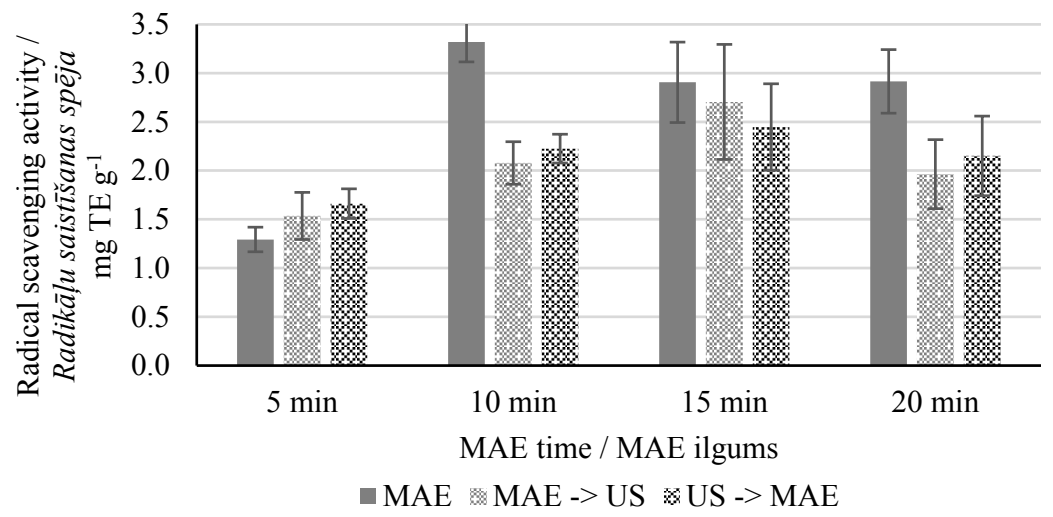

Fig. 17. Free radical scavenging activity of produced extracts depending on the extraction method /

17. att. Ekstraktu brīvo radikālı saistī̌sanas spēja atkarībā no ekstrakcijas metodes

$\mathrm{TE}$ - trolox equivalent / troloksa ekvivalents; MAE - microwave assisted extraction

/ mikrovilnu veicināta ekstrakcija; MAE -> US - microwave assisted extracting followed by 5 min of ultrasound treatment / mikrovilnu veicināta ekstrakcija ar sekojošu 5 min ultraskannas iedarbību; US -> MAE - 5 min of ultrasound treatment

followed by microwave assisted extraction / 5 min ultraskanas iedarbïba ar sekojošu mikrovilı̣n veicinātu ekstrakciju. The data is presented as a mean $(\mathrm{n}=9)$ / Dati uzrādìti kā vidējās vērtības $(n=9)$.

Based on the BAC distribution between capsule surface and total phenolic content that can be seen in Fig. 18, encapsulation efficiency of produced capsules reached $95.5 \pm 0.9 \%$. This value should be considered as too big, because capsule had been formed of the same polarity substances. As a result, homogenous matrix should be formed and encapsulation efficiency should be a function of surface-to-volume ratio, and surface should be increased together with the decrease of capsule size. As an example, previous studies of gallic acid encapsulation in low dextrose equivalent starch showed encapsulation efficiency of $77 \pm 7 \%$ for spray dried samples.

There could be couple of reasons for such a high number. First of all, BAC could be mechanically separated from the surface during the encapsulation process itself. Due to their light weight, BAC then could be separated in the cyclone and withdrawn from the dryer together with the airflow. On the opposite side, it had been discussed earlier in the present work that (during the spray-drying process) carbohydrates could overcome the glass transition point and form sticky capsule surface that resulted in the uneven capsule forms. As a result, BAC could become surrounded with the carbohydrate capsule matrix and be entrapped strong enough that they could not be extracted with a pure EtOH (as it was performed in present study, as 
carbohydrates are not dissolvable in the $\mathrm{EtOH}$ ), as small molecular weight carbohydrates didn't release BAC due to the mechanical interactions. Deeper study of the capsule surface is necessary for more precise conclusions.

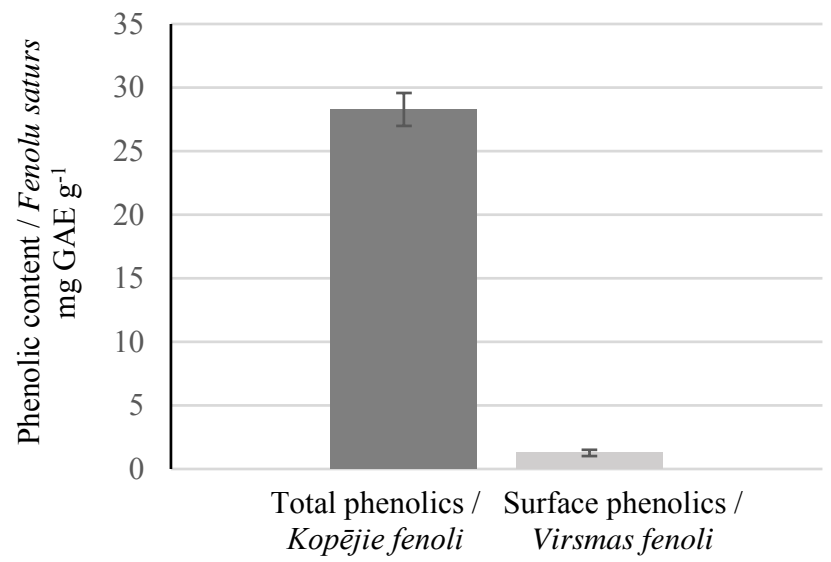

Fig. 18. Total and surface phenolic contents of produced capsules / 18. att. Pagatavoto kapsulu kopējais un virsmas fenolu saturs

The data is presented as a mean $(\mathrm{n}=3)$ /

Dati uzrādīti kā vidējās vērtības $(n=3)$.

There are several approaches that could be used to improve upon the current product. First, assuming that there is too large proportion of low molecular weight carbohydrates in the sample extract, a low DE maltodextrin (4-10) could be added to the mixture before feeding it into the spray-dryer. Secondly, different extraction solvent combinations with lower ethanol content could be used to increase solubility of longer chain dextrins. But it is important to take into consideration that decreases in ethanol concentrations could negatively influence phenolic compound extraction yields (Wu et al., $2012 \mathrm{~b}$ ), addition of organic acid could be necessary for better carbohydrate solubility and to maintain high phenol extraction levels (high taking in consideration total extractable phenol content in potato peel sample).

All five stages of the developed method took a half of a day in the laboratory conditions, with most of the time spent on the solvent evaporation and recovery. It had been planned that on the production scale all process should take less than one work day, based on the available concentration technology. Due to the chosen MAE and concentration stages, present method is suitable for production process that consists of separate batches. This is a great choice for a small scale production lines that could be used in Latvia, due to the relatively small potato processing amounts in the first place. 


\section{Encapsulated recovered biologically active compound application to reduce meat oxidative damage}

In previous chapters, two different encapsulation methods had been developed, dry (multiphase capsules) and liquid (simultaneous extraction of phenolic compounds and carbohydrates) BAC extract encapsulation. They also could be combined, when encapsulated BAC in the carbohydrate matrix would be additionally incorporated into the solid palm oil core and covered with maltodextrin shell.

Taking in consideration all technical aspects, that were discussed in previous chapters, it had been decided to continue present research using a second method of simultaneous BAC and carbohydrate extraction with further concentration and spray-drying, as it is faster and don't require previous extraction and dehydration of the core material. In the present part, the produced encapsulated BAC from the previous study stage were added to a ground pork meat for lipid oxidation inhibition. Due to the big amount of time required to prepare enough encapsulated BAC in laboratory conditions, it was decided to conduct a proof of concept storage study, when encapsulated BAC were added to the ground pork meat mass, that further had been stored at $30 \pm 1^{\circ} \mathrm{C}$ for accelerated shelf-life testing.

Results of the research, showing that encapsulated BAC in the carbohydrate matrix are able to inhibit lipid oxidation, are represented in Fig. 19.

It can be seen that after one day of storage at $30 \pm 1{ }^{\circ} \mathrm{C}$, meat mass with added encapsulated BAC shows ca. five times lower oxidation rates than a control sample. Unfortunately, on the second day of storage oxidation rates of both samples were already similar. On the third day of the storage, microbial degradation of meat samples had been too big to allow quantitative determination of active oxygen. It can be evaluated as a positive results, as present research part had been conducted at the increased temperature.

Next logical research step (that could be continued in the future) could be to evaluate the degree of encapsulated BAC suitability for prolonged cold storage of meat, as an oxidation inhibitor. Additionally, it had been envisaged that phenolic compounds (that will remain at the end of cold storage) will never be wasted, as they will be consumed together with a prepared meal. As it had been stated above, extractable potato peel phenolics have a big positive benefits for human health. Number of studies reported a successful application of herbal extracts as natural antioxidants in meat and meat products (Cao et al., 2013; Devatkal et al., 2012; Grāmatina et al., 2017; Mathenjwa et al., 2012; Naveena et al., 2013; Nissen et al., 2004; Ozvural \& Vural, 2012; Reddy et al., 2013; Sánchez-Muniz et al., 2012). 


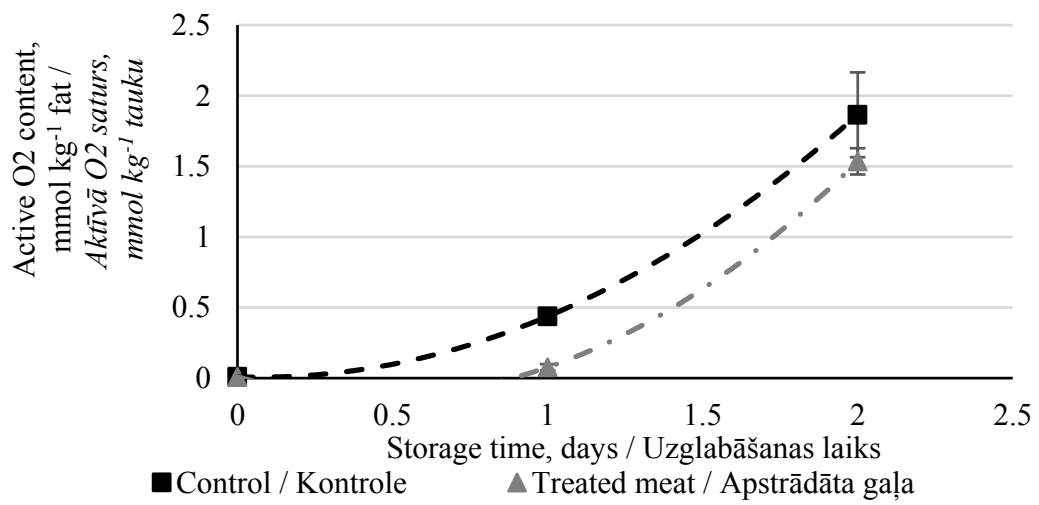

Fig. 19. Changes in the active oxygen content in the minced pork meat lipid fraction during the accelerated storage study /

19. att. Izmaiņas aktīva skābekḷ saturā maltas cūkgaḷas lip̄idu frakcijā, gaḷas uzglabäšanas laikā paātrinātos apstākḷos

$\mathrm{O}_{2}$ - active oxygen / aktīvais skäbeklis. The data is presented as a mean $(\mathrm{n}=3)$ / Dati tika uzrādīti kà vidējās vērtības $(n=3)$.

One of the major differences, between potato peel samples acquired in laboratory condition and acquired from the actual potato processing facility, is that on the production sites peel by-products usually are being collected with an assistance of water, and, as had been stated previously, water is a second food-grade solvent for phenolic compound extraction after ethanol. Of course, additional assistance (mechanical, ultrasound, microwave, etc.) should be applied for better phenolic compound diffusion form the cells into the water, but still some BAC losses should be present. This means that previously reported data is not fully scalable for industrial application, as water and ethanol extracts results in the different phenolic profiles and different antioxidant properties (Farvin et al., 2012). 


\section{CONCLUSIONS}

1. Acquired results of the study confirm the proposed hypothesis: potato peel - an industrial potato processing by-product, can be utilized for phenolic compound recovery and encapsulation, for further applications in food production.

2. Two peel types, large $(4 \pm 1 \mathrm{~cm})$ and small $(4 \pm 1 \mathrm{~mm})$ peels, are suitable for biologically active compound recovery, and they could be stored at ambient conditions (open air, room temperature) for up to two days. Finely shredded peel is not suitable for biologically active compound extraction.

3. Comparing two studied encapsulation technologies (freeze- and spraydrying), no significant differences in the encapsulation efficiencies had been observed. Freeze-drying samples showed very porous structure, that can result in accelerated oxygen diffusion into capsules and faster oxidation of the encapsulate.

4. Method for potato peel processing had been developed that allows simultaneous biologically active compound (encapsulate) and carbohydrate (encapsulant) extraction with further microencapsulation by spray-drying.

5. Additional microencapsulation method had been developed that allows production of multiple phase capsules. During the capsule formation, encapsulated phenolic compound is evenly distributed between core and shell wall materials. This fact can be considered as negative or positive (assuming that shell wall gallic acid can be released in the surrounding media in order to provide antioxidative and antiradical protection for the mentioned media).

6. Microencapsulated biologically active compound incorporation into the ground pork meat is able to decrease meat oxidation rate during the meat storage at accelerated oxidation conditions. 


\section{PĒTĪJUMA AKTUALITĀTE}

Gadiem ilgi kartupeḷi (Solanum tuberosum L.) ir viena no pasaulē nozīmīgākajām cilvēku patēriņam izmantotajām lauksaimniecības kultūrām līdztekus kviešiem (Triticum L.), rīsiem (Oryza L.) un kukurūzai (Zea mays subsp. mays L.). 2016. gadā visā pasaulē tika saražoti 374 miljoni tonnu kartupeḷu, tostarp 497 tūkstoši tonnu Latvijā (FASOTAT, Crops, s.a.). Dažās attīstītajās valstīs līdz pat 70\% (2012. gadā) no kopējā saražoto kartupelu daudzuma tiek pārstrādāti (U.S. per Capita ..., s.a.). Latvijas ekonomika piedzīvo stabilu izaugsmi, un kartupeḷu pārstrādes apjomu pieaugumu varētu sagaidīt arī nākotnē.

Parasti kartupeḷu rūpnieciskā pārstrāde ietver mizošanu (lietojot abrazīvo vai tvaika mizošanas metodi), kas var radīt līdz $40 \%$ atkritumu no sākotnējās kartupeḷu masas atkarībā no mizošanas metodes, galaprodukta un sākotnējās kartupeḷu bumbuḷu kvalitātes (Arapoglou et al., 2009). Tehnisku iemeslu un normatīvā regulējuma dēl mizu (kā rūpnieciskās kartupeḷu pārstrādes blakusproduktu (IPPB)) apsaimniekošana un pārstrāde rada lielas problēmas kartupeḷu pārstrādes nozarē. Statistikas dati liecina, ka 2015. gadā Eiropā tika pārstrādāti kartupel̦i 9,4 miljardu eiro vērtībā, kas veido 1.1\% no Eiropas pārtikas un dzērienu nozares kopējās vērtības (The EU potato sector, 2018).

Kartupeḷu mizas ir viens no galvenajiem kartupeḷu pārstrādes blakusproduktiem ar plašām izmantošanas perspektīvām pārtikā (Arapoglou et al., 2009). Pēc ķīmiska sastāva IPPB ir lēts blakusprodukts, kas satur lielu daudzumu cietes, citus polisaharīdus un lignīnu. Pārāk lielā šķiedru satura dēl mizas bez specializētas pirmapstrādes nav piemērotas neatgremotāju diētai (Birch et al., 1981). Pēdējā desmitgadē ir veikti daudzi teorētiski pētījumi par IPPB pārstrādi, bet pašreizējās izpētes periodā nav zināma neviena strādājoša pārstrādes rūpnīca. Šis fakts liecina par nepieciešamību izstrādāt jaunu rentablu un kompaktu metodi. Daudzi autori piekrīt, ka viena no perspektīvām kartupelı mizu pārstrādes iespējām pārtikas rūpniecībā varētu būt biologiski aktīvo savienojumu (BAC) ekstrakcija. Iegūto ekstraktu varētu izmantot pārtikas produktu bagātināšanai, lai aizkavētu to oksidāciju uzglabāšanas laikā. Lai ekstraktā saglabātu vajadzīgās antioksidatīvās īpašības, jānodrošina pietiekama BAC aizsardzība no pašoksidēšanās, pirms tie tiks izmantoti attiecīgajā ražošanas posmā. Viens no labākajiem risinājumiem šai problēmai varētu būt BAC mikrokapsulācija jeb iekḷaušana aizsargkapsulā. Tas nodrošinās kapsulētā savienojuma kontrolētu atbrīvošanu un samazinās potenciālo antioksidantu saskari ar skābekli.

Lai izstrādātu praktiski piemērojamu metodi kartupeḷu mizu (kartupeḷu rūpnieciskās pārstrādes blakusprodukta) pārstrādei, pētījumā uzmanība koncentrēta uz BAC ekstrakcijas optimizāciju un mikrokapsulāciju, ņemot vērā, ka iekapsulēto ekstraktu paredzēts izmantot kā antioksidantu maltā cūkgaḷā. 
Promocijas darba hipotēze: kartupeḷu mizas - kartupeḷu rūpnieciskās pārstrādes blakusprodukts - ir noderīga izejviela fenolu savienojumu izdalīšanai un kapsulācijai, un šie savienojumi ir izmantojami pārtikas ražošanā.

Pētījuma objekts - Latvijā rūpnieciski pārstrādāto kartupeḷu (Solanum tuberosum L.) mizas.

Promocijas darba mērḳis ir izstrādāt praktiski lietojamu kartupeḷu mizu pārstrādes metodi mikrokapsulētu bioloğiski aktīvo vielu (pārsvarā fenolu savienojumu) ekstrakta ieguvei.

Darba mērḳa sasniegšanai izvirzīti šādi uzdevumi:

1. izvērtēt kartupeḷu mizas - kartupeḷu rūpnieciskās pārstrādes blakusproduktu -, kas pieejams kartupel̦u pārstrādes uzñēmumos Latvijā;

2. analizēt ekstrahējamo biolog̣iski aktīvo vielu saturu un stabilitāti abrazīvi atdalītās kartupeḷu mizās;

3. salīdzināt izplatîtākās pārtikas klases metodes ekstrahēto bioloǵiski aktīvo savienojumu mikrokapsulācijai;

4. izstrādāt metodi mikrokapsulēto fenolu savienojumu ekstrakcijai no kartupeḷu pārstrādes blakusprodukta (mizām), izvērtējot iegūtā produkta funkcionalitāti pārtikas produkta ražošanā.

\section{Zinātniskais nozīmīgums}

1. Izstrādāta oriǵināla kompleksa metode kartupel̦u mizu blakusproduktu pārstrādei un kapsulēto fenolu savienojumu ražošanai.

2. Izpētîta vienlaicīga biologiski aktīvo vielu (pārsvarā fenolu savienojumu) un og̣̣hidrātu (paredzēti kā kapsulu nesējviela) ekstrakcija un vēlāka mikrokapsulācija.

3. Izvērtēts iegūtā produkta kā potenciāla antioksidanta lietojums gaḷas industrijā.

\section{Tautsaimnieciskais nozīmīgums}

1. Izstrādāta praktiski lietojama, dabai draudzīga un kompakta (veicama vienas dienas laikā) kartupeḷu blakusproduktu pārstrādes metode, kas ḷauj iegūt jaunus produktus.

2. Iegūtais kapsulētais produkts ir izmantojams pārtikas produktu ražošanā, lai aizkavētu to oksidēšanos un pagarinātu uzglabāšanas laiku.

\section{ZINĀTNISKĀ DARBA APROBĀCIJA}

Pētījuma rezultāti apkopoti 5 zinātniskos izdevumos, ieskaitot 3 publikācijas, kas indeksētas starptautiskās citējamības datubāzēs SCOPUS un Web of Science. 
Par rezultātiem ziṇots 7 starptautiskās zinātniskās konferencēs Braz̄ilijā, Igaunijā, Indijāa, Krievijas Federācijā, Latvijā un Lietuvā (publikāciju un prezentāciju sarakstus skatīt 6.-7. lpp.).

\section{MATERIĀLI UN METODES}

\section{Pētījuma laiks un vieta}

Promocijas darbs izstrādāts no 2014. līdz 2018. gadam Latvijas Lauksaimniecības universitātes un Minesotas universitātes (ASV) zinātniskajās laboratorijās.

\section{Pētījuma struktūra}

Pētījums izstrādāts trijos secīgos posmos, kas atspoguḷoti 1. attēlā.

Pētîjuma pirmais posms bija veltîts galvenokārt informācijas vākšanai par iespējamo kartupeḷu rūpnieciskās pārstrādes blakusproduktu izmantošanu pārtikā un faktiskās situācijas izvērtējumam kartupeḷu pārstrādes rūpnīcās Latvijā. Tā kā vairākums uzṇēmumu neizrādīja vēlmi sadarboties, informāciju un paraugus izdevās iegūt tikai no šādiem uzņēmumiem:

1. SIA "Īves Grupa", Leveste, Jaunpils pagasts, Jaunpils novads;

2. A/S “Orkla Confectionery \& Snacks Latvija" (bijušais A/S "Latfood"), pašlaik lielākais kartupeḷu pārstrādes uzṇēmums Latvijā;

3. SIA "Nissi", Rīga;

4. SIA "Paplāte Nr. 1", Raubēni, Cenu pagasts, Ozolnieku novads.

Pēc savākto kartupeḷu mizu paraugu k̦īmiskajām analīzēm un iegūto datu izvērtējuma izpētîti ekstrahējamo BAC noārdīšanās ātrumi atšķirīgi nomizotos mizu paraugos, kas tika uzglabāti nekontrolējamos apstākḷos atklātos konteineros telpas temperatūrā, pasargāti no tiešas gaismas, kā tas notiktu reālā kartupeḷu pārstrādes rūpnīcā Latvijā (2. att.).

Lai standartizētu un imitētu dažādu kartupeḷu mizu veidus (kas tika iegūti iepriekšèjā posmā), kā izejmateriāls paraugu sagatavošanai tika izvēlēta rūpnieciskās kategorijas kartupeļu şķirne (Solanum tuberosum cv 'Magdalena', genotips 82-28.9/15876.41). Kartupeḷu paraugus nodrošināja Agroresursu un ekonomikas institūta Priekuḷu pētniecības centrs (bijušais Valsts Priekuļu laukaugu selekcijas institūts).

Pēc uzglabāšanas apstākḷu ietekmes uz bioloǵiski aktīvo vielu stabilitāti kartupel̦u mizās novērtēšanas tika sperts nākamais solis, lai izanalizētu biežāk lietotās pārtikas klases mikrokapsulācijas metodes (liofilizācija un mikrokapsulācija izsmidzināšanas kaltē; 3. att.). Minētās metodes nav salīdzināmas, un šā posma galvenais mērḳis bija izpētīt, vai liofilizācijas metodes izmantošana var būt pamatota salīdzinājumā ar BAC mikrokapsulāciju izsmidzināšanas kaltē (kas ir lētāka un pieejamāka 
metode). Šāds pētījums bija nepieciešams, jo daudzos citos pētījumos liofilizācijas metode tika izvēlēta kā piemērotākā BAC mikrokapsulācijai.

Galluskābe (GA) kā fenola savienojums tika izvēlēta, lai nodrošinātu pētījuma kontroles apstākḷus, jo tā ir izplatīta dabā, izmantojama pārtikā, pieejama un salīizinoši stabila.

Pamatojoties uz iegūtajiem rezultātiem, izsmidzināšana kaltē tika izraudzīta kā mikrokapsulācijas metode šajā pētījumā. Nākamais pētījuma posms tika veltīts tam, lai izstrādātu alternatīvu metodi sausa, ūdenī šḳ̄stoša fenola savienojuma mikrokapsulācijai vairāku slāṇu kapsulā vienā izsmidzināšanas procesā (4. att.). Parasti līdzīgas metodes ietver vairākus posmus: 1) kapsulējamās vielas iekḷaušanu kapsulas kodolā un 2) papildu ārējā apvalka veidošana. Šajā pētījumā izstrādātā metode ḷauj ietaupīt laiku un samazināt ražošanas procesa izmaksas. Turklāt, lai ārējais apvalka slānis būtu izturīgāks, neliels daudzums modificētās cietes (izvēlētais ārējā apvalka materiāls) bija pārvērsts par retrogradētu cieti. Tāpat kā iepriekšējā posmā, galluskābe tika izmantota kā fenola savienojumu paraugs.

Pēc iegūto rezultātu rūp̄igas analīzes tika sperts nākamais solis, kura mērķis - nodrošināt efektīvu un ātru BAC ekstrakciju no rūpnieciski pieejamām kartupeḷu mizām un BAC ekstrakta mikrokapsulāciju (5. att.). Lai to sasniegtu, tika izstrādāta vienlaicīga BAC (kapsulējamās vielas) un cietes hidrolīzes produktu (kapsulas matricas materiāla) ekstrakcija. Bija plānots, ka mikrokapsulācijas laikā (izsmidzināšanas kaltē) iegūtie og̣̣hidrāti veidos aizsargapvalku ap BAC. Šajā procesā kartupeļu miza ir vienīgā izejviela, kas padara izstrādāto metodi par praktisku kartupel̦u mizu pārstrādes veidu.

Promocijas darba pēdējā posmā aprakstîti iepriekš iegūto kapsulu praktiskas izmantošanas piemēri. Kapsulas tika pievienotas svaigai maltai cūkgaḷai (proporcijās $2 \mathrm{~g}$ BAC uz $1 \mathrm{~kg}$ cūku tauku) oksidācijas procesu inhibēšanai uzglabāšanas laikā (6. att.). Pagatavotā maltās gaḷas masa tika uzglabāta 6 dienas paātrinātas oksidācijas apstākḷıs $30 \pm 1{ }^{\circ} \mathrm{C}$ temperatūrā. Katru dienu tika paņemts neliels gal̦as paraugs, iepakots vakuumā, ātri sasaldēts un uzglabāts $-20^{\circ} \mathrm{C}$ temperatūrā līdz turpmākām analīzēm.

\section{Pētījumā pielietotās metodes}

Izmantotās analīžu metodes apkopotas 1. tabulā

\section{Statistiskā analīze}

Datu matemātiskā analīze tika veikta $M S$ Excel v16 un R 3.4.1. programmatūrās, lietojot a) Diksona Q testu, b) ANOVA, c) Tjūkija testu un d) t-testu. Atškirīības starp vērtībām uzskatāmas par nebūtiskām, ja $P>0.05$. 


\section{REZULTĀTI UN DISKUSIJA \\ 1. Kartupeḷu industriālas pārstrādes blakusproduktu (mizu) izvērtējums}

Izvērtējot visus Latvijā pieejamos kartupeḷu rūpnieciskās pārstrādes blakusproduktus (IPPB), tika nolemts turpināt pêtījumus par kartupeḷu mizu pārstrādi. Lēmuma pamatā bija stabila izejmateriālu pieejamība Latvijas uzṇēmumos. Šajā kategorijā var ietilpināt arī veselus kartupeḷu bumbuḷus, ņemot vērā samazinātu ekstrahējamo biologiski aktīvo savienojumu (BAC) koncentrāciju (jo vairāk BAC atrodas mizās).

Pētītos mizu paraugus var iedalīt trīs grupās: 1) lielas mizas $(4 \pm 1 \mathrm{~cm})$, 2) mazas mizas $(4 \pm 1 \mathrm{~mm})$ un 3$)$ sasmalcinātas mizas. Savākto paraugu kīmisko analīžu rezultāti pieejami 2. tabulā.

Jāuzsver, ka visi mizu paraugi tika savākti no reālām kartupeḷu pārstrādes līnijām un uzṇēmumi (izṇemot tikai vienu lielāko Latvijā) pieņem pārstrādei vienlaicīgi vairākas šķirnes. Līdz ar to katrs savāktais paraugs bija vairāku genotipu sajaukums un analīzes rezultāti tika salīdzināti ar literatūrā pieejamiem datiem.

Mazo mizu paraugos tika konstatēts četras reizes lielāks lipīdu saturs, salīdzinot ar vidējām teorētiskajām vērtībām $(8.1 \pm 0.3$ pret $1.6 \pm$

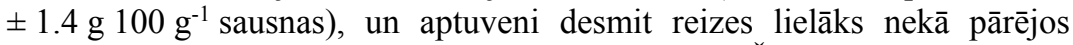

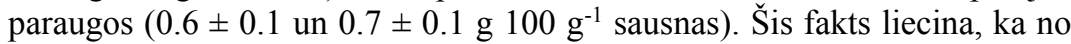
vairākām ražošanas līnijām paņemtu mizu sajaukšana pārstrādes rūpnīcās uzskatāma par nopietnu problēmu. Šajā gadījumā mizu paraugi tika sajaukti ar daḷu no brāḳētā gala produkta - ceptiem kartupeḷu čipsiem.

Pārējo kīmisko savienojumu saturs paraugos bija teorētiskajās robežās un ar maznozīmīgām atšķirībām. Iepriekš tika ziņots, ka no kartupeḷu mizām iegūtās olbaltumvielas ir augstākas kvalitātes salīdzinājumā ar lielāko daḷu augu olbaltumvielu, bet sensorās îpašības samazina to izmantošanas potenciālu pārtikas sistēmās (Mu et al., 2009). Papildus patlaban liels zinātniskā darba apjoms ir paveikts olbaltumvielu atdalīšanā, attīī̄̌sanā un oksidatīvās brūnēšanas inhibēšanā (Arogundade \& Mu, 2012; Mu et al., 2009; Schmidt et al., 2018). Tādēl, ņemot vērā dārzeņu rūpnieciskās pārstrādes blakusproduktu kā škiedrvielu avotu izmantošanas pārtikas ražošanā popularitāti, tika nolemts turpmākos pētījumus koncentrēt uz bioloǵiski aktīvo savienojumu un cietes ekstrakciju un izmantošanas iespējām pārtikā.

\section{Ekstrahējamo bioloğiski aktīvo vielu stabilitāte kartupeḷu pārstrādes blakusproduktos}

Ekstrahējamo biolog̣iski aktīvo vielu profils ir ḷoti atkarīgs no daudziem faktoriem, ieskaitot kartupeḷu škirni, uzglabāšanas laiku un apstākḷus, sezonu 
un audzēšanas apstākḷus. Turklāt visbiežāk katrs kartupeḷu pārstrādes uzṇēmums (jo īpaši Latvijā) izmanto sev piemērotākās šķirnes. Līdz ar to (un ņemot vērā, ka BAC saturs kartupeḷos ir plaši aprakstīts literatūrā) autors promocijas darbā koncentrējas uz BAC ekstrakciju kopumā, neanalizējot atsevišķus kartupeḷu genotipus.

Rezultāti rāda, ka uzglabāšanas laikā nekontrolējamos apstākḷos ekstrahējamie fenolu savienojumi ir stabilāki lielākajos mizas paraugos (lielās un mazās mizās) nekā sasmalcinātajos mizas paraugos. Pirmajās minūtēs pēc nomizošanas visi mizu paraugi sāka brūnēt, un tas liecina par fermentatīvo reakciju norisi. Vámos-Vigyázó (1981) rakstīja, ka esošie enzīmi kartupẹ̦os (polifenolu oksidāzes (PPO)) katalizē monofenolu pārvēršanos par o-difenoliem un o-dihidroksilfenolu transformāciju par ohinoniem.Pēc tam hinona produkti var polimerizēties un reaǵēt ar šūnu olbaltumvielu aminoskābju grupām, veidojot brūno pigmentu. Thygesen $e t$ al. (1995) parādīja, ka visaugstākā PPO aktivitāte konstatējama subepidermā (ārējā mizu slānī) 1.5-2.0 mm dziḷumā. Tas ir slānis, ko noṇem ar abrazīvās mizošanas metodēm, kuras lieto kartupeḷu pārstrādes uzṇēmumos Latvijā.

Mizu uzglabāšanas laika ietekmi uz kopējo fenolu saturu paraugos var redzēt 7. att. Statistiskā analīze neuzrādīja būtiskas atškirīibas starp lielajām un mazajām mizām. Kopējais fenolu savienojumu saturs pirmajās divās uzglabāšanas dienās bija stabils, bet trešajā dienā būtiski samazinājās - par $40 \%$ salīdzinājumā ar iepriekšējo dienu vidējām vērtībām. Savukārt sasmalcinātajā mizā fenolu savienojumu saturs ievērojami - par $66 \%$ samazinājās jau otrajā uzglabāšanas dienā. No tā var secināt, ka mizu fizikālais stāvoklis tieši ietekmē BAC stabilitāti paraugos. Sasmalcinātajos mizu paraugos PPO ir brīva pieeja BAC, kuru degradācija paātrinās arī mikrobiolog̣iskās iedarbības dēḷ. Savukārt lielajās un mazajās mizās veselās šūnas rada aizsargājošu efektu.

Kartupeḷu mizu uzglabāšanas laika ietekme uz to ekstrakta spēju saistīt brīvos radikālus parādīta 8 . attēlā. Pēc pirmās uzglabāšanas dienas visi trīs mizu paraugi neuzrādīja būtiskas antiradikālās aktivitātes izmaiņas. Otrajā dienā sasmalcinātās mizas bija zaudējušas $97 \%$ no brīvo radikāḷ saistīšanas spējas, turpretī lielo uz mazo mizu paraugu aktivitāte palika iepriekšèjā līmenī. Tikai trešajā uzglabāšanas dienā veselie mizu paraugi sāka parādīt nozīmīgu antiradikālās aktivitātes kritumu.

Korelācijas līknei starp kopējo fenolu saturu un brīvo radikāḷu saistīšanas spēju ir polinoma raksturs (9. att.). Ir labi zināms, ka kafijskābe un tās esteris (hlorogēnskābe) ir divi galvenie fenolu savienojumi kartupeḷos (Solanum tuberosum L.) un abiem piemīt antiradikāla aktivitāte (Al-Weshahy \& Rao, 2009; Habeebullah et al., 2010; Mattila \& Hellström, 2007; Sánchez Maldonado et al., 2014; Singh \& Saldaña, 2011; Wu et al., 2012b).

Zinātniskajā literatūrā norādīts: kafijskābes esterificēšana ar cukura atlikumu samazina tās antioksidatīvo aktivitāti (Cuvelier et al., 1992). 
Turpretī hlorogēnskābei mazāka antioksidatīivā aktivitāte vērojama kukurūzas eḷıā (Chen \& Ho, 1997). Koncentrācijās 0.5, 1.0 un $2.0 \mathrm{mM}$ kafijskābei piemīt labāka radikāḷu saistīšanas spēja saulespuķu eḷıāa (Milic et al., 1998) un tā labāk inhibē lipīdu oksidāciju zivju muskuḷos (Medina et al., 2007). Turpretī jaunākie pētījumi rāda, ka cukura atlikumu piesaiste kafijskābei palielina antioksidantu aktivitāti un samazina ūdeṇraža peroksīdu un DPPH• radikāḷla saistīšanas spējas (Sroka \& Cisowski, 2003).

Marinova et al. (2009) konstatēja, ka hlorogēnskābes un kafijskābes antioksidatîvā un antiradikālā aktivitāte saulespuķu eḷıā ir lıti atkarīga no to koncentrācijas un pie $2.8 \times 10-4 \mathrm{M}$ abas skābes uzrāda vienādu efektivitāti un izturību, bet, palielinot koncentrāciju virs $10 \times 10-4 \mathrm{M}$, kafijskābe ir daudz efektīvāks un spēcīgāks inhibitors.

Parasti hlorogēnskābe ir visbagātīgākais fenolu savienojums kartupeḷos. Bet, uzglabājot mizas telpas temperatūrā vai gaismā, hlorogēnskābe noārdās un pārvēršas par kafijskābi (Sotillo et al., 1994). Pamatojoties uz savāktajiem datiem, var pieņemt, ka autora pētījumā pēc nomizošanas paraugos bija liels hlorogēnskābes saturs. Kad fenolu kopējais daudzums sāka samazināties, hlorogēnskābe noārdījās un kafijskābe tika izdalīta pietiekamā daudzumā, lai noturētu ekstrakta brīvo radikāḷu saistīšanas spēju augstā līmenī, un kopējais fenolu saturs nesamazinājās zem 3.0 mg GAE g${ }^{-1}$ (9. att.), kad kafijskābes koncentrācija kḷuva pārāk zema.

Hlorogēnskābes un fenilalanīna degradācijas dinamika parādīta 10. attēlā. Paraugi, kas sastāv no lielām un mazām mizām, uzrādīja l’oti līdzīgu tendenci. Savukārt sasmalcinātajās mizās hlorogēnskābe gandrīz nebija sastopama jau tūlīt pēc mizošanas. Tas ir piln̄̄gas šūnu sabrukšanas rezultāts, kad augu sekundārie metabolīti sāk nomākt oksidatīvo stresu un ar to saistītos molekulāros bojājumus, izmantojot vairākus iespējamos reakcijas ceḷus, kas ir sīki aprakstīti zinātniskajā literatūrā (Fifen et al., 2011; Galano et al., 2016; Tošović et al., 2017).

Kopumā var redzēt, ka hlorogēnskābes koncentrācija paraugos, kas satur veselas šūnas (lielas un mazas mizas), samazinājās lēnāk pirmo uzglabāšanas dienu laikā, bet vēlāk noārdīšanās ātrums strauji pieauga. Savukārt fenilalanīna koncentrācijas samazināšanās visaktīvāk norisinājās tajā pašā uzglabāšanas laikā un bija lineārāka turpmākajās uzglabāšanas dienās. Rezultātā varētu pieņemt, ka pirmajās uzglabāšanas dienās varētu turpināties hlorogēnskābes sintēze no fenilalanīna. Bet turpmākajās dienās reakciju komponenti un katalizatori varētu kḷūt neaktīvi vai sabrukt, apturot reakcijas norisi. Sasmalcinātajās mizās, kurās hlorogēnskābe tikpat kā nav sastopama, fenilalanīna saturs sāka samazināties tikai trešajā uzglabāšanas dienā. Pamatojoties uz straujajiem samazinājuma rādītājiem, tas varētu būt mikrobiologiskās iedarbības rezultāts.

Divu kartupeḷu mizu paraugu izplatītāko glikoalkaloīdu savienojumu ( $\alpha$-solanīns un $\alpha$-čakonīns) noārdīšanās grafiki parādīti 11. attēlā. 
Iegūto datu lineārā aproksimācija rāda, ka $\alpha$-solanīna noārdīšanās ātrums vislēnākais ir lielajās mizās. Mazās mizas uzrādīja līdzīgu rezultātu, bet tajās $\alpha$-solanīna noārdīšanās ātrums bija jau lielāks. Sasmalcinātajos mizu paraugos visi bioloǵiski aktīvie savienojumi (tostarp glikoalkaloīdi, hlorogēnskābe un fenilalanīns) bija vairāk pakḷauti ārējās vides un enzīmu (kas tika atbrīvoti šūnu bojājumu ietekmē) iedarbībai, un katra identificētā savienojuma noārdīšanās ātrums bija augstāks salīdzinājumā ar citiem paraugiem. Jāuzsver, ka paraugi tika uzglabāti atklātos konteineros un daḷa gaismas staru, kas atstarojās no telpas sienām, varētu sasniegt paraugus un izraisīt papildu glikoalkaloīdu veidošanos. Šis fakts varētu izskaidrot nelielu $\alpha$-solanīna satura pieaugumu trešajā un ceturtajā uzglabāšanas dienā. Tādējādi var secināt: ja kartupelıu pārstrādes blakusproduktos (mizās) ir saglabājušās veselas šūnas un glikoalkaloīdu veidošana nav vēlama, mizas turpmākai pārstrādei ieteicams uzglabāt tumsā.

\section{Liofilizācijas un izsmidzināšanas kaltes metožu salīdzinājums galluskābes mikrokapsulācijai}

Lai pēc iespējās pilnīgāk koncentrētos uz kapsulācijas tehnologijām un samazinātu iespējamos mainīgos lielumus, galluskābe tika izmantota vairākiem turpmākiem eksperimentiem kā ūdenī šḳ̂̄stošs fenola modeḷsavienojums. GA mikrokapsulācijas efektivitāte, izmantojot liofilizāciju (FD) un mikrokapsulāciju izsmidzināšanas kaltē (SD), parādīta 12. attēlā. Statistiskā analīze neuzrādīja būtiskas atškirirības $(P>0.05)$ starp abām metodēm, un bija iespējams sasniegt mikrokapsulācijas efektivitāti $72 \pm 7 \%$ FD un $77 \pm 7 \%$ SD paraugiem.

SD un FD kapsulu paraugi vizuāli redzami 13. attēlā. Atšķirības virsmas morfoloǵijā ir atkarīgas no izvēlētās mikrokapsulācijas tehnoloǵijas, darba apstākḷiem un parametriem. SD paraugiem ir sfēriska forma izsmidzināšanas kaltes darbības procesa dēḷ. Šajā gadījumā škidrais paraugs tika izsmidzināts kaltěšanas kamerā, veidojot apalı pilieninus virsmas spraiguma ietekmē. Pilienini ātri saraujas, jo mitrums strauji iztvaiko. Savukārt FD dalinịām ir neregulāra forma, tās ir monolītas un ḷoti atškirīgas pēc izmēra. FD kapsulu formu un struktūru noteica arī mikrokapsulācijas process, kurā šķidrais paraugs tika ātri sasaldēts, nofiksējot GA mikrokapsulācijas materiāla matricā. Pēc sasalšanas un kaltēšanas matrica tika saberzta, veidojot nenoteiktas formas dalinas.

Kapsulu virsmas parametri, kas noteikti, izmantojot Barrett-JoynerHalenda (BJH) slāpekḷa desorbcijas un Dubinina-Raduškeviča (DR) mikroporu analīžu metodes, apkopoti 3. tabulā. FD paraugi parādīja lielāku kumulatīvo desorbcijas virsmas laukumu (no 0.632 līdz $1.225 \mathrm{~m}^{2} \mathrm{~g}^{-1}$ ) un lielāku kumulatīvo desorbcijas poru tilpumu (no $2.4 \times 10^{-3} \mathrm{li} \mathrm{dz} 9.5 \times 10^{-3} \mathrm{~cm}^{3} \mathrm{~g}^{-1}$ ) nekā SD paraugi (attiecīgi no $0.472 \times 10^{-3} \mathrm{li} \mathrm{dz} 1.296 \times 10^{-3} \mathrm{~cm}^{2} \mathrm{~g}^{-1}$ un no $1.2 \times 10^{-3} \mathrm{li} \mathrm{dz}$ 
$\left.4.9 \times 10^{-3} \mathrm{~cm}^{3} \mathrm{~g}^{-1}\right)$. DR metodes rezultāti liecina par mikroporu klātbūtni FD kapsulas virsmā, vidējais mikroporu virsmas laukums - no 1.028 līdz $2.229 \mathrm{~m}^{2} \mathrm{~g}^{-1}$, kas ir mazāks nekā SD paraugos (no $1.108 \mathrm{lī} \mathrm{z} 2.374 \mathrm{~m}^{2} \mathrm{~g}^{-1}$ ).

Lielāka porainība un lielāks kopējais virsmas laukums nozīmē straujāku iekapsulētā materiāla izdalīšanos no kapsulas un sliktāku aizsardzību, jo lielāka kapsulu virsma nonāk saskarē ar ārējo vidi (Zuidam \& Shimoni, 2010). Kopumā fenolu savienojumus uzskata par termostabiliem (Im et al., 2011), kas padara SD par piemērotāku mikrokapsulācijas tehnolog̣iju. No otras puses, ja nepieciešams aizsargāt dārgu un termiski sensitīvu savienojumu, FD ir lieliska mikrokapsulācijas metode, jo ir ekonomiski efektīvāka ilgai uzglabāšanai nekā parastā sasaldēšana un uzglabāšana negatīvās temperatūrās, kas prasa pat lielāku energijjas patērinuu (Lorentzen, 1979).

\section{4. Ūdenī šḳistošo fenolu savienojumu mikrokapsulācija vairākslāṇu kapsulā}

Ūden̄̄ šḳistošo fenolu savienojumu aizsardzībai trīs fāžu kapsulu veidošanas sistēma (cietais lipīdu kodols, kas satur ūdenī šḳ̂̄stošu fenola savienojumu, ir pārklāts ar modificētas cietes apvalku) tika radīta vienā izsmidzināšanas procesā. Šì metode tika izveidota kā alternatīva esošajām daudzfāžu mikrokapsulācijas tehnoloğijām, kur 1) vispirms mērķa savienojumu iekḷauj cietā kodolā un 2) pēc tam kodolu pārklāj ar aizsargslāni. Lai palielinātu ārējā og̣̣hidrātu apvalka izturību, daļa modificētās cietes (MS; izvēelêtais kapsulu materiāls šajā pētījumā) tika pārveidota par retrogradēto cieti (RS) (Dimantov et al., 2004; Eerlingen et al., 1993; Janaswamy, 2014), apstrādājot MS autoklāvā $121 \pm 1^{\circ} \mathrm{C}$ temperatūrā ar turpmāku inkubāciju $22 \pm 2,68 \pm 2$ un $100 \pm 2{ }^{\circ} \mathrm{C}$ (Eerlingen et al., 1993).

Saražotajās kapsulās GA aptuveni vienmērīgi sadalījās starp kodola un apvalka frakcijām, neliela daudzums GA palika uz kapsulas virsmas (14. att.). Tas ir GA difūzijas rezultāts $\mathrm{O} / \mathrm{W}$ emulsijas veidošanas laikā, kad $\mathrm{O}$ fāze (lipīdu kodols, kas satur GA) tika sajaukta ar W fāzi (maltodekstrīna škīidums) pirms emulsijas padeves izsmidzināšanas kamerā. Iespējams, ka emulgatora koncentrācijas palielinājums var izveidot stabilāku sistēmu un samazināt GA difūziju no lipīdu fāzes, radot spēcīgāku hidrofobo polaritāti. Izveidotajās kapsulās lipīdu fāze nodrošina mikrokapsulētās GA aizsardzību pret saskari ar ūdeni un citiem hidrofiliem savienojumiem.

Holser (2013) parādīja, ka ferulskābe (ūdenī škīistošs fenolu savienojums ar antioksidējošām īpašībām), kas iekapsulēta lipīdu matricas kapsulās, bija stabila 3 mēnešu laikā, ja to uzglabāja apkārtējās vides apstākḷos. Citā pētījumā lipīdu nanodaḷiņas, kas tika ievietotas ūdenī, varēja stabilizēt (-)epigallokatehīna-3-galātu četru nedēḷu laikāa, kamēr nekapsulēts (-)epigallokatehīna-3-galāts (izšḳīināts ūdenī) uzrādīja 100\% degradāciju 4 stundu laikā (Barras et al., 2009). Pašreizējā pētījumā izmantotās lipīdu frakcijas kušanas temperatūra ir $50{ }^{\circ} \mathrm{C}$. Tas ḷauj secināt, ka mikrokapsulētā 
GA ir labi aizsargāta no apkārtējās vides faktoriem. Tā ir ne tikai iekapsulēta hidrofobā kodolā, bet arī pārklāta ar papildu MS apvalku, kas aizsargā izkausēto lipīdu fāzi no noplūdes un kapsulu aglomerācijas, ja kapsulu uzglabāšanas temperatūra pārsniedz $50^{\circ} \mathrm{C}$.

Rezultāti (14. att.) rāda, ka liela daḷa no kopējās mikrokapsulētās GA bija izkliedēta ūdens fāzē parauga sagatavošanas laikā un tika fiksēta MS matricā. Šajā pêtījumā izmantotajai MS raksturīgas lieliskas emulǵējošās un mikrokapsulācijas īpašības un spēja maskēt mikrokapsulēto savienojumu nevēlamo smaržu un garšu, tostarp rūgto fenolu piegaršu (Spinelli et al., 2016). Tas nozīmē, ka GA apvalkā var uzskatīt par aizsargātu, līdz kapsula nonāks saskarē ar ūdens fāzi vai citu piemērotu šķ̄ininātāju, kas izšķ̄indinās apvalka materiālu vai izraisīs GA difūziju no MS fāzes apkārtējā vidē.

Pamatojoties uz aprakstītajiem aspektiem, var pieņemt, ka saražotās kapsulas varētu izmantot dažādiem pārtikas produktiem (maltajai gaḷai, zivīm, mīklai), kuru fenolu savienojumi tiks atbrīvoti no MS apvalka un nonāks apkārtējā vidē. Atbrīvotie fenolu savienojumi varētu darboties kā antioksidanti pašā pārtikas produktā. Ja temperatūras paaugstināšanās nebūs apvienota ar intensīvu maisīšanu, kas sabrūkt lipīdu kodolu (kā desu ražošanā), lipīdu fāzes fenolu savienojumi paliks nofiksēti un aizsargāti, līdz kapsulas nonāks cilvēka gremošanas sistēmā. Wada \& Fang (1992) pierādīja, ka fenolu savienojumi spēj nomākt polinepiesātināto taukskābju oksidāciju saldētā sasmalcinātā gaḷā. Veselos un samaltos gaḷas produktos fenolu savienojumi efektīvi aizkavēja nevēlamas smakas, garšas un krāsu izmainas (Shah et al., 2014). Līdzīgi rezultāti tika iegūti, pētot ar radiāciju apstrādātu galu (Kanatt et al., 2005) un samaltu skumbriju (Farvin et al., 2012). Fenolu savienojumi pozitīvi ietekmē cilvēka veselību, jo samazina oksidatīvo stresu (Singh \& Rajini, 2004, 2008).

Tikai neliels GA daudzums tika konstatēts uz kapsulu virsmas: no $2.3 \pm 0.2 \%$ līdz $3.8 \pm 0.6 \%$. Šo GA daudzumu var uzskatīt par zudumiem, aprēķinot kopējo mikrokapsulācijas efektivitāti $97.1 \pm 0.4 \%$.

Saražotās kapsulas var uzskatīt par stabilām un uzglabājamām apkārtējā vidē. Piemēram, nekontrolētas temperatūras palielināšanās gadījumā kapsulas apvalks saglabā integritāti, nepazeminot pulverveida produkta kvalitāti, kā tas var notikt kapsulu transportěšanas laikā vasaras sezonā. Tā kā ciete nav reaktīvs materiāls, kapsulām nav vajadzīgi īpaši uzglabāšanas apstākḷi un iepakojuma materiāls, izṇemot aizsardzību pret pārmērīgu mitrumu (lai novērstu apvalka salipšanu un GA difūziju un šḳīīibu). Tas samazina uzglabāšanas izdevumus un kopējo kapsulu ražošanas cenu. 


\section{Vienlaicīga fenolu savienojumu un og̣̣hidrātu ekstrakcija ar sekojošu mikrokapsulāciju}

Iepriekšejā nodaḷā izstrādātā mikrokapsulācijas metode ir piemērota BAC iekḷaušanai vairākfāžu kapsulās, kas nodrošina labu BAC aizsardzību gan hidrofilā, gan hidrofobā vidē. Šajā pētījumā autors mēgeinājis apvienot BAC mikrokapsulāciju ar kartupeḷu mizu pārstrādi, panākot vienlaicīgu BAC (iekapsulējamā viela) un og̣̣idrātu (kapsulu matricas materiāls) ekstrakciju. Līdz ar to pašreizējā pētniecības posma galvenais mērḳis ir izstrādāt kompaktu, vienkāršu un ātru kartupeḷu mizu pārstrādes metodi mikrokapsulētu BAC ražošanai, ja iespējams, izmantojot tikai pamata iekārtas (15. att.).

Izstrādātā metode paredz, ka kartupeḷu mizas var pārstrādāt bez speciāla iepriekšēja sagatavošanas procesa ( $k \bar{a}$, piemēram, kaltēšanas vai šķirošanas). Vien̄̄gais priekšnoteikums, kas izriet no iepriekš iegūtajiem rezultātiem, mizām jāsatur veselas šūnas, kuras nodrošinās lielāku BAC iznākumu.

Pētījumā izmantoti mizu paraugi no abrazīvās mizošanas līnijām, jo tvaika mizošanas tehnologijas pētījuma norises laikā Latvijā nebija pieejamas kartupeḷu pārstrādes apjoma dēḷ. Pētījums tika veikts atbilstīgi ražošanas apstākḷiem Latvijā.

Izstrādātais ekstrakcijas-kapsulācijas process sastāv no pieciem soḷiem.

1. Kartupeḷu mizu savākšana tieši no pārstrādes līnijas, lai nodrošinātu minimālu piesārņojumu ar citiem pārstrādes blakusproduktiem (piemēram, ellı).

2. Mizu sajaukšana ar šķīdinātāju (60\% etanolu) un homogenizācija. Šis process ietver arī pirmo ekstrakcijas posmu - konvencionālo ekstrakciju, kuras laikā pirmie BAC un og̣̦hidrāti sāk difundēt šḳīinātājā. Svarīgi ir maksimāli sasmalcināt šūnas, lai nodrošinātu labāku šķīdinātāja piekḷuvi masai. Autora pētîjuma ietvaros izmantota šķīdinātāja-mizu attiecība $10: 1$ (mL:g).

3. Galvenais ekstrakcijas solis. Autora pētījumā pārbaudītas divu ekstrakcijas metožu (mikroviḷnu un ultraskaņas veicinātas ekstrakcijas) kombinācijas, lai nodrošinātu labāko attiecību starp BAC iznākumu un izmantoto enerǵijas patērinu.

Ekstrakcija norisinājās 5, 10, 15 un 20 minūtes. 16. attēlā redzams BAC iznākums un 17. attēlā - brīvo radikāḷu saistīšanas spēja atkarībā no ekstrakcijas metodes.

Rezultāti rāda, ka īsākajā ekstrakcijas laikā (5 min.) iegūta zemākā BAC koncentrācija ekstraktos, bet paraugos, kuru ekstrakcijas laiks bija 10 minūtes, konstatēts augstākais BAC iznākums. No pārējiem paraugiem (15 un $20 \mathrm{~min}$ ) iegūti sliktāki rezultāti nekā no parauga, kas ekstrahēts 10 minūtes, bet labāki nekā no parauga, kas ekstrahēts 5 minūtes. Papildu ultraskaņas apstrāde deva pozitīvu rezultātu tikai paraugiem ar visīsāko ekstrakcijas laiku, pārējos paraugos BAC koncentrācija tās ietekmē 
samazinājās. Iegūtie rezultāti atbilst iepriekš aprakstītajiem (Wu et al., 2012a).

Kā redzams 17. attēlā, paraugiem, kas ekstrahēti 10 minūšu laikā, piemīt arī vislielākā brīvo radikālu saistī̌anas spēja, kura samazinās pēc ultraskaņas lietošanas. Tas varētu nozīmēt, ka piln̄̄gi ekstrahēti fenolu savienojumi noārdās (16. att.), ja tos pakḷauj pārāk lielai slodzei. Pamatojoties uz iegūtajiem rezultātiem, autors nolēma izlaist paraugu papildu apstrādi ar ultraskaņu un tālākiem pētījumiem izmantot tikai mikrovilı̣u veicinātu ekstrakciju.

4. Iegūtie ekstrakti tika koncentrēti vakuuma ietvaices iekārtā, lai sasniegtu divus galvenos mērḳus:

a. atgūtu šķīininātāju atkārtotai ekstrakcijai (sākotnējo etanola koncentrāciju var atjaunot, izmantojot šḳīinātāja blīvumu);

b. samazinātu parauga tilpumu, lai samazinātu enerǵijas un laika patēriņu nākamajam posmam - mikrokapsulācijai.

Pēc koncentrēšanas paraugus uzglabāja vakuumā, lai samazinātu fenolu savienojumu reakciju ar brīvajiem radikāliem un skābekli, kas atrodas gaisā.

5. Saražotā ekstrakta mikrokapsulācija izsmidzināšanas kaltē. Papildu izejvielas netika pievienotas, jo esošais ekstrakts satur nepieciešamo BAC un oglhidrātu daudzumu.

Ir paredzēts, ka var notikt vairāki mikrokapsulācijas procesi. Pirmkārt, veidosies matricas tipa kapsulas, jo gan BAC, gan og̣̣hidrāti ir ūdenī šḳisstoši savienojumi (ar vienādu polaritāti), kas veidos homogēnu struktūru. Mazmolekulāro cukuru apvalks veidos labu barjeru, kas samazinās skābekḷa difūziju kapsulā un iespējamo BAC oksidāciju. Otrkārt, var būt iespējama amilozes iekḷaušanas kompleksu veidošana, kad BAC molekulas tiks iekḷautas amilozes k̦ēžu sistēmās.

Teorētiski iespējams saražoto mikrokapsulēto BAC papildu lietojums pagatavotās kapsulas var izmantot kā specializētu materiālu citu vērtīgu un dārgu savienojumu mikrokapsulācijai, lai nodrošinātu to aizsardzību pret oksidāciju. Piemēram, tās varētu izmantot eḷıas (ar lielu nepiesātināto taukskābju saturu) mikrokapsulācijai, jo fenolu savienojumi kapsulu apvalkā veiksmīgi nodrošinās papildu aizsardzību pret skābekḷa un brīvo radikāḷu difūziju kapsulu kodolā (elı̣ā). Turklāt ir zināms, ka dažiem ūdenī šks̄istošiem polisaharīdiem, kas ekstrahēti no kartupeḷu mizām, piemīt labas ūdens un tauku saistǐšanas un putu veidošanas (olbaltumvielu atlieku klātbūtnes dēḷ) spējas, dabiskās antioksidatīvās īpašības un tie stabilizē emulsijas (Khawla et al., 2016). Līdz ar to var secināt, ka pagatavotās BAC-ogḷhidrātu kapsulas noder kā mikrokapsulācijas materiāls, piemēram, lietošanai farmakologiijā, kur sevišķi liela uzmanība ir veltīta dārgu aktīvo savienojumu aizsardzībai.

Pamatojoties uz BAC satura sadalījumu uz kapsulas virsmas un kopējo fenola saturu (18. att.), aprēḳinātā mikrokapsulācijas efektivitāte sasniedz 
$95.5 \pm 0.9 \%$. Šì vērtība jāuzskata par pārāk lielu, jo kapsulas bija izveidotas no vienādas polaritātes komponentiem, veidojot viendabīgu matricu. Līdz ar to mikrokapsulācijas efektivitātei jābūt kā funkcijai no virsmas laukuma un tilpuma attiecības (samazinoties kapsulas izmēram, palielinās kopējais virsmas laukums). Piemēram, iepriekšējos pētījumos par galluskābes mikrokapsulāciju cietes matricas kapsulās izsmidzināšanas kaltē pagatavoto paraugu mikrokapsulācijas efektivitāte bija tikai $77 \pm 7 \%$.

Tik augstai mikrokapsulācijas efektivitātei iespējami vairāki cēloṇi. Pirmkārt, BAC var būt mehāniski atdalītas no virsmas paša mikrokapsulācijas procesa laikā. N̦emot vērā to mazo svaru, BAC var būt atdalītas ciklonā un aizvadītas kopā ar gaisa plūsmu. No otras puses, kā pētījumā tika konstatēts iepriekš, mikrokapsulācijas laikā izsmidzināšanas kaltē mazmolekulāro og̣̣hidrātu klātbūtnes dēl kapsulu formējošais materiāls varētu sasniegt stiklošanās temperatūru, veidojot ḷoti lipīgu kapsulas virsmu, kas izraisa kapsulu aglomerāciju un nevienmērīgas formas rašanos. Tā ietekmē BAC varētu būt stiprāk iesaistīti og̣̣hidrātu kapsulu matricā un nebūt pieejami ekstrakcijas škīdinātājam (96\% etanolam), jo cieta kapsulu virsma varētu mehāniski mijiedarboties ar BAC, tos noturot. Lai iegūtu precīzākus secinājumus, nepieciešams dziḷāks kapsulas virsmas pētījums.

Ir vairākas pieejas, ko var izmantot, lai uzlabotu pašreizējo produktu. Pirmkārt, ņemot vērā lielo mazmolekulāro og̣̣hidrātu saturu, ekstraktam var būt pievienots maltodekstrīns ar zemu dekstrozes ekvivalentu (4 vai 10), kas varētu palielināt stiklošanās temperatūru un samazināt aglomerāciju kapsulu veidošanas laikā. Otrkārt, lai palielinātu lielmolekulāro og̣̣hidrātu šḳīīibu, iespējams samazināt etanola koncentrāciju šķīdinātājā, bet tas var pazemināt ekstrahēto BAC iznākumu (Wu et al., 2012b). Treškārt, pazeminātu etanola koncentrāciju var kombinēt ar organisko skābju (piemēram, etiķskābes) pievienošanu, kas varētu nodrošināt augstāku BAC iznākumu (ņemot vērā kopējo ekstrahējamo fenola saturu kartupeḷu mizu paraugā).

Visi pieci izstrādātās metodes posmi laboratorijas apstākḷ os aizṇēma mazāk par vienu dienu, lielāko daḷu laika aizṇēma šḳīinātāja iztvaicēšana. Plānots, ka rūpnieciskās ražošanas laikā viss process aizņems mazāk nekā vienu dienu, jo tiks izmantotas pieejamās koncentrēšanas tehnologijas. Ṇemot vērā pētījuma laikā pieejamos mikroviḷnu veicinātas ekstrakcijas un ekstrakta koncentrēšanas posmus, pašreizējā metode sastāv no atsevišķu produkta partiju pārstrādēm (metode pagaidām nevar darboties nepārtraukti). Tā ir lieliska izvēle maza mēroga ražošanas uzņēmumiem Latvijā.

\section{Mikrokapsulēto bioloğiski aktīvo savienojumu pielietojums gaḷas oksidatīvo bojājumu samazināšanai}

Iepriekšējās nodaḷās aprakstīts divu BAC mikrokapsulācijas metožu izstrādes process. Pirmā ir paredzēta sausa parauga mikrokapsulācijai 
daudzfāžu kapsulā, otrā ietver vienlaicīgu BAC un og̣̣hidrātu ekstrakciju un vēlāku mikrokapsulāciju izsmidzināšanas kaltē. Abas metodes var kombinēt papildu aizsardzības nodrošināšanai - kapsulas, kas iegūtas, vienlaicīgi ekstrahējot BAC un og̣̣hidrātus, var būt papildus mikrokapsulētās daudzfāžu kapsulās. Ṇemot vērā visus tehniskos aspektus, kas apspriesti iepriekšejāās nodạ̦ās, pētījumi turpināti, izmantojot vienlaicīgas BAC un oģ̣hidrātu ekstrakcijas metodi, jo tā 1) paredz kapsulu ražošanu, tieši pārstrādājot kartupel̦u mizas, un 2) neprasa iepriekšēju BAC ekstrakciju un dehidrēšanu kā citas metodes, kuras paredzētas sausu paraugu mikrokapsulācijai.

Šajā pētījumu posmā iepriekš sagatavotās kapsulas tika pievienotas maltai cūkgaļai lipīdu oksidācijas inhibēšanai. N̦emot vērā lielo laika apjomu, kas nepieciešams pietiekami liela kapsulu daudzuma sagatavošanai laboratorijas apstākḷos, koncepcijas pārbaudes pētījums veikts, uzglabājot sagatavotus gaḷas paraugus paātrinātas oksidācijas apstākḷos $30 \pm 1{ }^{\circ} \mathrm{C}$.

Rezultāti liecina, ka mikrokapsulētās BAC spēj veiksmīgi aizkavēt lipīdu oksidāciju (19. att.).

Pēc pirmās uzglabāšanas dienas cūkgalas masai, kurai pievienotas kapsulas, konstatēta aptuveni piecas reizes zemāka oksidācijas pakāpi nekā kontrolparaugam. Otrās dienas beigās abu paraugu oksidācijas pakāpes pieauguma temps bija līdzīgs, un tas liecina par BAC antioksidatīvās aktivitātes izbeigšanos. Pēc trešās uzglabāšanas dienas mikrobiologiiskā iedarbība gaḷas paraugos bija pārāk liela, lai būtu iespējama kvantitatīva analīze. Kopumā rezultātu var novērtēt kā pozitīvu, jo pašreizējā izpēte speciāli tika veikta paaugstinātā temperatūrā.

Nākamais logiskais izpētes solis (ko varētu turpināt nākotnē) varētu būt iepakotas gal̦as ilgtermiņa uzglabāšana aukstumā $\left(4{ }^{\circ} \mathrm{C}\right)$, lai noteiktu mikrokapsulēto BAC spēju pagarināt paraugu uzglabāšanas laiku reālos uzglabāšanas apstākḷos pārtikas industrijā. Turklāt ir paredzēts, ka fenolu savienojumi (kas saglabās aktivitāti aukstās uzglabāšanas beigās) netiks pazaudēti, jo tie tiks patērēti kopā ar sagatavoto maltīti. Kā iepriekš minēts, no kartupeḷu mizām ekstrahētie fenoli ir milzīgs ieguvums cilvēka veselībai un daudzos pētījumos aprakstîta augu izcelsmes ekstraktu kā dabīgu antioksidantu veiksmīga izmantošana dažādos gaḷas produktos (Cao et al., 2013; Devatkal et al., 2012; Grāmatina et al., 2017; Mathenjwa et al., 2012; Naveena et al., 2013; Nissen et al., 2004; Ozvural \& Vural, 2012; Reddy et al., 2013; Sánchez-Muniz et al., 2012).

Viena no būtiskākajām atšķirībām starp kartupeḷu mizu paraugiem, kas iegūti laboratorijas apstākḷos, un paraugiem no kartupeḷu pārstrādes līnijām ir tā, ka ražošanas laikā mizas parasti tiek savāktas un aizvadītas ar ūdens palīdzību. Kā norādīts iepriekš, ūdens ir otrs populārākais pārtikā izmantojams šḳīinātājs fenolu savienojumu ekstrakcijai pēc etanola. Protams, jāpiemēro papildu apstrāde (smalcināšana, ultraskaṇas vai mikroviḷnu iedarbība utt.), lai panāktu labāku fenolu savienojumu difūziju 
šḳīinātājā, bet joprojām neliels BAC daudzums tiks pazaudēts ar notekūdeņiem. Tas nozīmē, ka iepriekš aprakstītie dati nav pilnībā izmantojami rūpnieciskajā ražošanā, jo ūdens un etanola ekstrakti veido atšḳirīgus fenolu savienojumu profilus ekstraktos, kas arī uzrāda atšķirīgas antioksidatīvas īpašības (Farvin et al., 2012). 


\section{SECINĀJUMI}

1. Pētījumā iegūtie rezultāti apstiprina izvirzīto hipotēzi: kartupeḷu mizas kartupeḷu rūpnieciskās pārstrādes blakusprodukts - ir noderīga izejviela fenolu savienojumu izdalīšanai un kapsulācijai, un šie savienojumi ir izmantojami pārtikas ražošanā.

2. Divu veidu mizas - lielas $(4 \pm 1 \mathrm{~cm})$ un mazas $(4 \pm 1 \mathrm{~mm})$ - ir piemērotas biolog̣iski aktīvo vielu ekstrakcijai, un tās var uzglabāt nekontrolējamos apstākḷos (atklātā gaisā, telpas temperatūrā) līdz divām dienām. Piln̄̄gi sasmalcinātas mizas nav piemērotas bioloǵiski aktīvo vielu ekstrakcijai.

3. Salīdzinot divas pētītās mikrokapsulācijas tehnoloǵijas pārtikas ražošanā (liofilizācija un mikrokapsulācija izsmidzināšanas kaltē), netika novērotas būtiskas atškirīibas galluskābes mikrokapsulācijas efektivitātē. Liofilizētiem paraugiem piemīt ḷoti poraina struktūra, kas var paātrināt skābekḷa difūziju kapsulā un izraisīt mikrokapsulētā savienojuma oksidāciju.

4. Pētījuma gaitā izstrādāta kartupeḷu mizu pārstrādes metode, kas ḷauj no kartupeļu mizām vienlaicīgi ekstrahēt biologiski aktīvās vielas un mikrokapsulācijas apvalka materiālu, tālāk veidojot matricas tipa kapsulas ar mikrokapsulācijas metodi izsmidzināšanas kaltē.

5. Izstrādāta arī mikrokapsulācijas metode, kas piemērota daudzfāžu kapsulu veidošanai (cieto lipīdu kodols ar maltodekstrīna apvalku). Ūdenī šḳīstošie fenoli vienmērīgi sadalās starp kapsulas lipīdu un maltodekstrīnu fāzēm. Šo faktu var vērtēt gan negatīvi (ja galluskābe maltodekstrīna fāzē tiek uzskatīta par zudumiem), gan pozitīvi (pieņemot, ka, izmantojot kapsulas pārtikas produktā, galluskābe tiks izdalīta apkārtējā vidē, nodrošinot paša produkta aizsardzību no oksidācijas).

6. Mikrokapsulēto biolog̣iski aktīvo savienojumu pievienošana maltai cūkgaḷai spēj samazināt tauku oksidācijas pakāpi uzglabāšanas laikā paātrinātas oksidācijas apstākḷos. 